\title{
Stakeholders' views on sustaining honey bee health and beekeeping: the roles of ecological and social system drivers
}

\author{
Mariia Fedoriak (1) - Oleksandr Kulmanov • Alina Zhuk • Oleksandr Shkrobanets • \\ Kateryna Tymchuk - Galyna Moskalyk - Tetiana Olendr • Taras Yamelynets • \\ Per Angelstam
}

Received: 17 November 2019/Accepted: 19 November 2020/Published online: 5 February 2021

(C) The Author(s) 2021

\begin{abstract}
Context Honey bees provide multiple ecosystem services. Comparisons of coupled social-ecological systems (SES) can improve the understanding of the factors affecting honey bees and beekeeping.

Objectives Stressing the need for SES analyses, we explore beekeepers' perceived factors affecting bees and beekeeping, test the hypothesis that honey bee colony losses are associated to agricultural land use intensity, and discuss the role of beekeeping for rural development.

Methods We used as a case study the steep gradient in SES in Ukraine's Chernivtsi region with three
\end{abstract}

M. Fedoriak $(\bowtie) \cdot$ O. Kulmanov .

A. Zhuk - O. Shkrobanets - K. Tymchuk - G. Moskalyk Department of Ecology and Biomonitoring, Chernivtsi National University, 2 Kotsyubynskyi Street,

Chernivtsi 58012, Ukraine

e-mail: m.m.fedoriak@gmail.com

M. Fedoriak · P. Angelstam

School for Forest Management, Faculty of Forest

Sciences, Swedish University of Agricultural Sciences

(SLU), PO Box 43, 73921 Skinnskatteberg, Sweden

T. Olendr

Department of Foreign Languages, Ternopil Volodymyr Hnatiuk National Pedagogical University, 2 Maxyma

Kryvonosa Street, Ternopil 46027, Ukraine

T. Yamelynets

Faculty of Geography, Ivan Franko National University, 41 Doroshenka Street, 79000 Lviv, Ukraine strata: (i) traditional villages, (ii) intermediate and (iii) intensive agriculture. In each stratum, we analysed the social system using five open-ended focus groups. Regarding the ecological system, we analysed data about winter loss rate of honey bee colonies, number of colonies per beekeeper, the average amount of supplemental feeding, and proportion of beekeepers treating against Varroa mite.

Results Thirty-three themes were extracted, of which $73 \%$ concerned the social system at multiple levels of governance. The number of themes increased from the traditional stratum with higher winter colony losses to the intensive agriculture stratum with lower losses. This does not support the hypothesis that the intensive agriculture per se affect honey bees negatively.

Conclusions Social system factors dominate over ecological factors, and interact across scales. This requires systems analyses of honey bees and beekeeping. We see beekeeping as a social innovation enhancing stakeholders' navigation in social systems, thus supporting rural development in countries in transition like Ukraine.

Keywords Social-ecological system $\cdot$ Ecosystem services · Honey bee $\cdot$ Rural development . Beekeeping practices 


\section{Introduction}

The western honey bee (Apis mellifera) is the globally most common, and since long time domesticated, bee species (Hung et al. 2018) for its production of honey and wax (Ruottinen et al. 2014), and later for its pollination activities (Kremen et al. 2007; Hung et al. 2018). This species is the single most important pollinator for agricultural crops. However, honey bees are increasingly threatened by pests and diseases, including the Varroa mite and associated virus infections, pesticides, land use and climate change (e.g., Steinhauer et al. 2018). Reducing the abundance and diversity of bees affects the pollination success of many cultural and wild plant species (Klein et al. 2006). In view of this, bees and other Hymenoptera (Sphecidae, Eumenidae, Pompilidae) are used as indicators of environmental changes (Steffan-Dewenter 2003; Wood et al. 2020). The honey bee has the longest tradition in research among social insects (Winston 1991). It has been used as a model organism in many fields of natural science research (e.g., understanding of animal communication (Von Frisch and Chadwick 1967), spatial orientation (Cartwright and Collett 1983), mechanisms of ageing (Münch et al. 2008), and collective decision making (Szopek et al. 2013).

By comparison, however, the social system dimensions of bee-human systems are rarely addressed, and there are few studies about beekeepers' perceptions to guide the understanding of bee health in different landscapes (Patel et al. 2020). Beekeeping as a practice is thus an interesting source of knowledge about the factors that affect the viability of the western honey bee, and also about beekeepers themselves in landscapes as coupled social and ecological systems (Sperandio et al. 2019). Beekeeping is predominantly a rural activity in traditional cultural landscapes world-wide (e.g., Ahmad et al. 2007; Fedoriak et al. 2019). Given the wide range of skills required to practise beekeeping including product procurement, collaborative capacity involving multiple sectors and levels of governance is needed. Beekeeping can thus be viewed as a social innovation that can enhance navigation in social systems (Ahmad et al. 2007; Fedoriak et al. 2019). This can empower stakeholders to deal also with other complex problems that require collaborative capacity. Comparisons of beekeeping practices and bee health among landscapes located in gradients from traditional agricultural systems based on multiple goods and services to intensively managed monoculture system can improve understanding of the importance of different driving factors. Thus, stakeholder engagement in knowledge production is needed. This is known to be beneficial in different ways, namely promoting links between science and society; gaining access to additional information or resources, and improving the relevance or utility of the research to users and beneficiaries (Durham et al. 2014).

As the theoretical framework supporting a systems perspective on landscapes as coupled human and nature systems, we chose the social-ecological system (SES) framework (see Partelow 2018 for a review). This is a comprehensive and multi-tiered conceptual framework for diagnosing both social systems focusing on governance interactions at multiple levels, and outcomes in social-ecological systems with a focus on their sustainability at multiple scales (Berkes and Folke 1998; Ostrom 2009). As a mainstream field of research, the SES concept has evolved into a systematic approach to understand how different SESs can be sustainable for people in places with different resource systems and units, governance systems and actors (e.g., McGinnis and Ostrom 2014). Within these main tiers, interactions and outcomes of SES with different socio-economic and political settings can be diagnosed (Partelow 2018). The study by Patel et al. (2020) provides a good example of applying the SES framework to the bee-human resource system.

Using a simplified version of the SES framework, focusing on social and ecological system factors at different levels of governance and spatial scales, the diversity of land use histories among local socialecological systems in different geopolitical units was used as a natural experiment design (sensu Diamond 1986) at the landscape scale. Countries with complex legacies of landscape history and governance systems allow using this approach. The European continent's West and East, linked to trajectories after the end of the Soviet Union, is a particularly useful example (Angelstam et al. 2013). Indeed, Ukraine has been termed a "cleft country" centred on the steepest part of the West-East gradient on the European continent (Katchanovski 2006). Ukraine has also a strong tradition of beekeeping, and is a major supplier of honey within Europe (Fedoriak et al. 2019). Here past trajectories of land use has led to large contrast 
between abundant remnants of traditional village system in remote locations, and emergence of intensive agriculture, which according to many studies has profound effects on bees and other insects (e,g., Vandame and Palacio 2010; Sánchez-Bayo and Wyckhuys 2019).

This study has three aims. First, we explore beekeepers' perceived factors at multiple levels affecting the viability of honey bees and beekeeping in different SES settings. Second, we test the hypothesis that honey bee colony losses are higher in landscapes with intensive agriculture accompanied with extensive use of pesticides than in the areas with traditional cultural landscapes. Third, we discuss the role of beekeeping as a social innovation that can support rural development. We collected data about the social system using focus groups, and about the ecological system using data from the international monitoring of honey bee colony losses, which also includes Ukraine.

\section{Methodology}

Case study region and stratification

We used as a case study the steep gradient in Ukraine's Chernivtsi region between traditional village livelihoods in remote mountain areas, and intensive agriculture with orchards and fields in lowlands. To capture this we divided the Chernivtsi region into three strata, each represented by one of this region's 11 districts, from west to east 'Traditional' Putyla, 'Intermediate' Storozhynets and 'Intensive agriculture' Khotyn (Fig. 1 and Table 1). The 'Traditional' stratum was the Putyla district, which is located in the eastern Carpathian Mountains and ranges from the Putyla river valley dominated by traditional selfsubsistence land use including home gardens and animal husbandry, to mixed and coniferous forests, and pastures above the tree line. Forestry is the other major land use there. The 'Intermediate' stratum (Storozhynets district) further to the east includes the Carpathian Mountain foothills with forestry, large villages where self-subsistence land use is important, and agricultural land with diverse crops. Finally, the 'Intensive agriculture' stratum (Khotyn district) in the east has many large villages with gardens, apple orchards, and agricultural land with soybean (Glycine max), rape seed (Brassica napus) and sunflower (Helianthus annuus) as important crops managed by big international agricultural businesses. Due to their distinct differences, the 'Traditional' and 'Intensive agriculture' strata are two extremes. The three selected districts were of similar size but varied considerably in forest cover from 67 to $16 \%$, and in the proportion of agricultural land used for crop production from 17 to $79 \%$. Multiple indicators demonstrate a very large contrast in agricultural intensity in terms of crops like wheat, potatoes, sunflowers and rape seed as well as orchards and berries, with 'Traditional' Putyla and 'Intensive agriculture' Khotyn as the extremes (Table 1).

To describe the three strata at the spatial scale viewed by honey bees as a home-range for foraging, we analysed land cover at a spatial extent of $5 \times 5 \mathrm{~km}$. This corresponds to an approximate radius of $2.5 \mathrm{~km}$ around fictive apiaries, which is consistent with the foraging ranges reported by Wenner et al. (1991). Using the land cover data produced by Broxton et al. (2014) we used GIS to calculate the proportions of seven land cover types (Table 1) for all $5 \times 5 \mathrm{~km}$ raster cells which were located to at least $50 \%$ (1250 ha) within each district. This resulted in 37,45 and 26 fictive honey bee home-ranges for the three districts, respectively (see Fig. 1).

To evaluate the extent to which the land cover distribution in local "honey bee landscapes" overlapped among the three strata we made a PCA ordination (Fig. 2). The first three principal components explained $94 \%$ of the variation. The first principal component explained $53 \%$ of the variation with CROP strongly associated to 'Intensive agriculture' Khotyn and MIXFOR to 'Traditional' Putyla (Table 2). Figure 3 shows the clear gradient between these two extremes, thus confirming the steep land cover gradient also at the spatial scale of bee foraging. Visual inspection of the PCA ordination plot (Fig. 2) shows that if both PCA1 and PCA2 are considered, there is no overlap between these two case study districts. The second principal component was finegradient land cover mosaic (MOSAIC), and the third was deciduous forest (DEC) (see Table 2). 


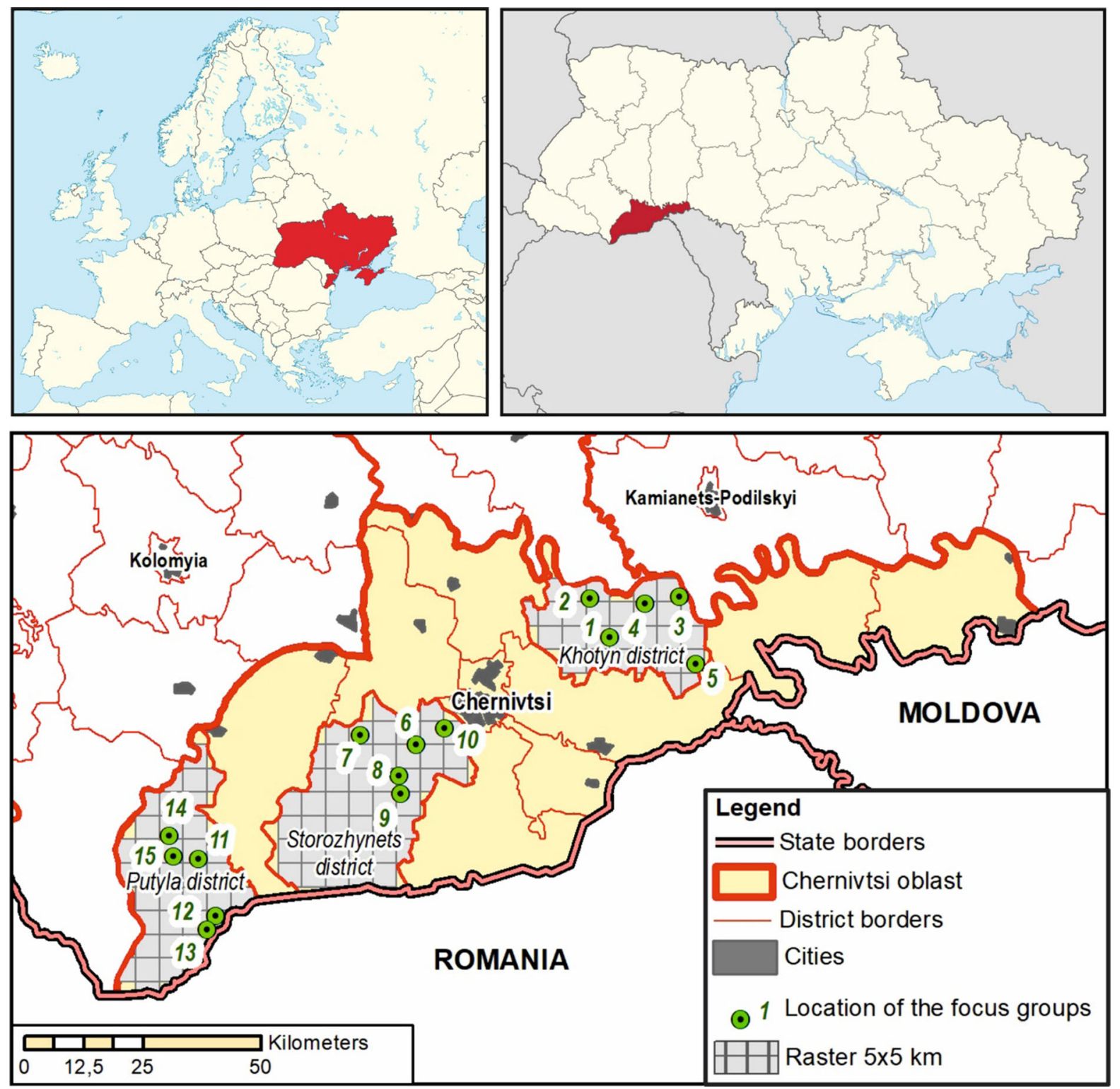

Fig. 1 Location of Ukraine's Chernivtsi region (oblast) in the eastern part of the European continent, and the three strata (districts) 'Traditional' Putyla, 'Intermediate' Storozhynets and 'Intensive agriculture' Khotyn located in the regional socialecological system gradient in Chernivtsi region. A total of five

\section{Methods}

\section{Social system}

First, in each of the three strata we organised five open-ended focus groups (Flick 2018) with 3-7 beekeepers in each (Fig. 1). Rural villages is a local focus groups were held in each of the three strata in spring and summer 2018 . The $5 \times 5 \mathrm{~km}$ raster represents the spatial scale of fictive honey bee apiaries' foraging area (see Table 1, Figs. 2 and 3)

characteristic unit throughout the study area, and village gardens are used for food production and fruit trees, and apiaries are usually located in beekeepers' village gardens. Only two of the 77 beekeepers had migratory apiaries. Thus, the data reflect where the rural settings where beekeepers live. The beekeepers were men, with exception for focus group number 6 


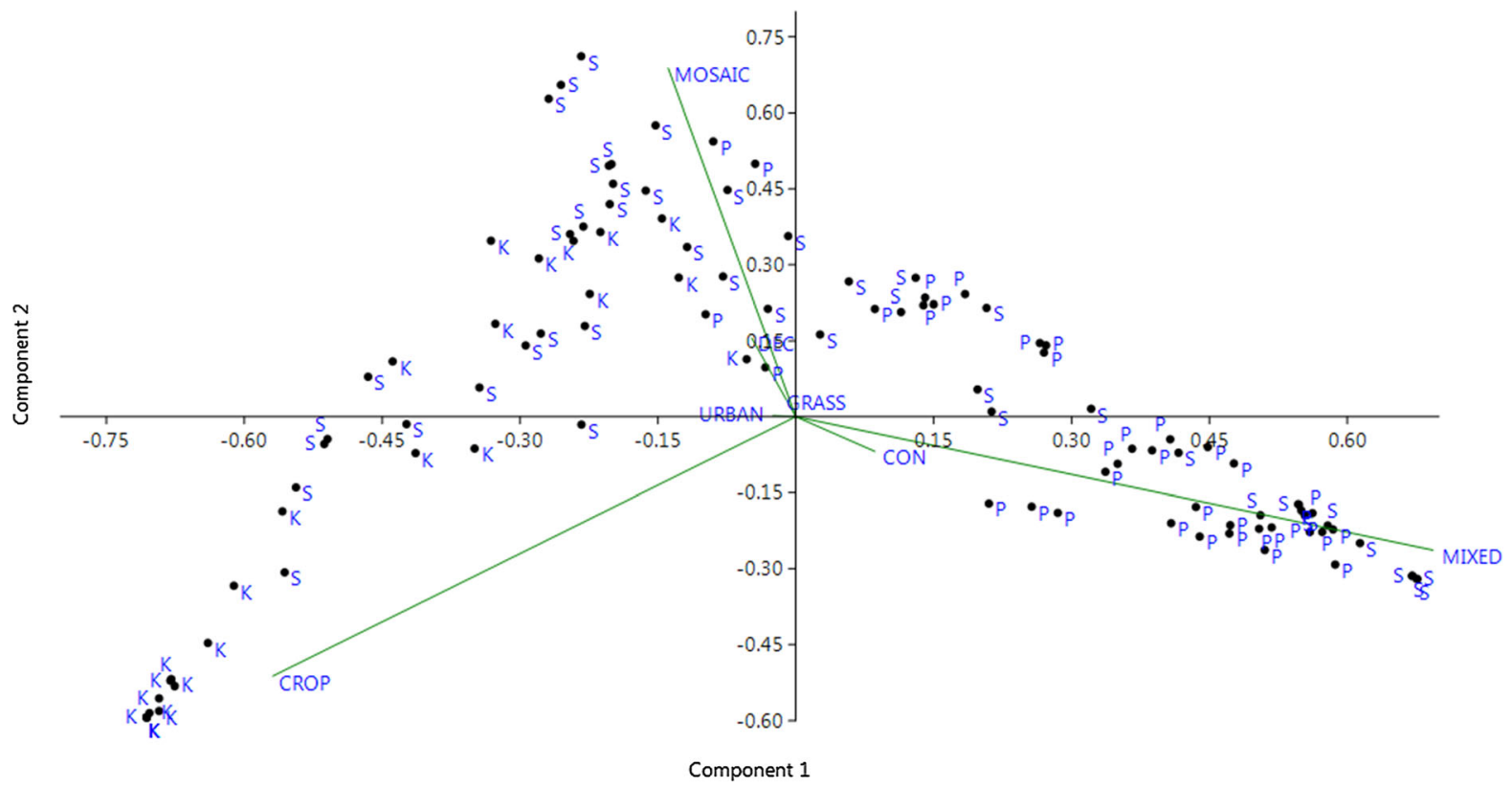

Fig. 2 PCA ordination based on the land cover proportions at the scale of fictive apiaries $(5 \times 5 \mathrm{~km}$ raster $)$ in the three strata (districts) (summary data in Table 1) 'Traditional' Putyla (P),
'Intermediate' Storozhynets (S) and 'Intensive agriculture' Khotyn (K) located in the regional social-ecological system gradient in Chernivtsi region

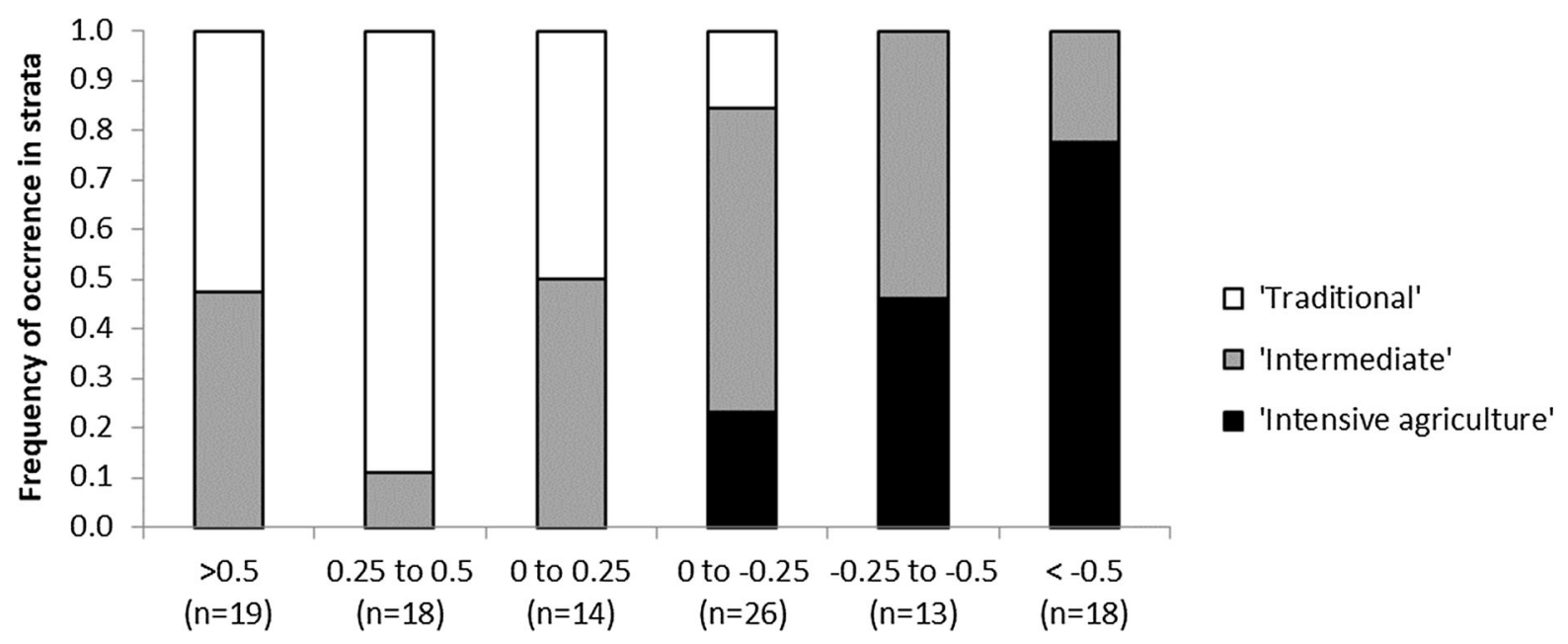

PCA 1 scores from mixed forest (left) to agricultural cropland (right)

Fig. 3 Distribution of raster cells belonging to the three strata along the PCA ordination's first principal component score, representing the gradient from mixed forest to agricultural

(see Fig. 1) which included one woman. The age of focus group participants ranged from 26 to 76 years, with the majority being $35-50$ years. This reflects the beekeeper gender situation and age distribution in Ukraine. Focus groups began by asking one short cropland based on the land cover proportions at the scale of fictive apiaries $(5 \times 5 \mathrm{~km}$ raster $)$

question: 'what the factors determine the well-being of bees and beekeepers?' The subsequent completely open-ended conversations lasted $1-2.5 \mathrm{~h}$. When the focus group conversation had ended, we asked the participants to list the key strengths, weaknesses, 
Table 1 Characteristics of three strata represented by the 'Traditional' stratum Putyla, the 'Intermediate' stratum Storozhynets, and the 'Intensive agriculture' stratum (Khotyn) in
Ukraine's Chernivtsi region (district level statistical data from Sarchynska 2017, and land cover data (Broxton et al. 2014) at the scale of honey bee apiaries $(5 \times 5 \mathrm{~km}$ raster, see Fig. 1)

\begin{tabular}{|c|c|c|c|c|}
\hline \multirow[t]{2}{*}{ Criteria } & \multirow[t]{2}{*}{ Variables (unit) } & \multicolumn{3}{|c|}{ Administrative unit (district) } \\
\hline & & Putyla & Storozhynets & Khotyn \\
\hline \multirow[t]{6}{*}{ Ecosystems } & Area $\left(\mathrm{km}^{2}\right)$ & 884 & 1160 & 716 \\
\hline & Altitude maximum (m) & 925 & 366 & 244 \\
\hline & Precipitation range (mm/year) & $800-1200$ & $650-900$ & $600-614$ \\
\hline & Annual mean temperature $\left({ }^{\circ} \mathrm{C}\right)$ & January -7 & January -6 & January -5 \\
\hline & & July +15 & July +17 & July +19 \\
\hline & Snow cover depth mean max (m) & 0.40 & 0.28 & 0.17 \\
\hline \multirow[t]{5}{*}{ Social system } & Population size (2017), persons & 26,400 & 100,300 & 62,200 \\
\hline & Proportion urban (2017) $(\%)$ & 13 & 24 & 15 \\
\hline & The average monthly nominal wage (UAH) & 2801 & 2410 & 2279 \\
\hline & $\begin{array}{l}\text { Human population density in } 2017 \text { (persons } \\
\mathrm{km}^{-1} \text { ) }\end{array}$ & 30 & 86 & 87 \\
\hline & $\begin{array}{l}\text { Natural increase, decrease }(-) \text { population, } \\
\text { persons }\end{array}$ & 220 & 577 & -330 \\
\hline \multirow[t]{8}{*}{ Economics } & $\begin{array}{l}\text { Agricultural products (total at constant prices in } \\
2010 \text { in M UAH) }\end{array}$ & 89.3 & 458.1 & 621.7 \\
\hline & of which plant growing & 17.4 & 267 & 485.1 \\
\hline & of which stock breeding & 71.9 & 191.1 & 136.6 \\
\hline & of which sheep and goats & 11.2 & 17.6 & 1.8 \\
\hline & $\begin{array}{l}\text { Agricultural land with wheat, potatoes, } \\
\text { sunflower and rape seed in } 2016 \text { (1000 ha) }\end{array}$ & 1.2 & 30.5 & 29.4 \\
\hline & $\begin{array}{l}\text { Sunflower } 2016 \\
\text { (1000 tons) }\end{array}$ & 0 & 5.6 & 1.2 \\
\hline & Orchards and berries (1000 tons), change & 0.5 to 0.8 & 3.8 to 10.9 & 10.9 to 72.5 \\
\hline & 2000-2016 & 1.6-fold & 2.9-fold & 6.7-fold \\
\hline \multirow{8}{*}{$\begin{array}{l}\text { Land cover proportions at the scale } \\
(5 \times 5 \mathrm{~km}) \text { of fictive apiaries }\end{array}$} & Sample size & 37 & 45 & 26 \\
\hline & Coniferous forest (CON) & 0.14 & 0.00 & 0 \\
\hline & Deciduous forest (DEC) & 0.02 & 0.05 & 0.14 \\
\hline & Mixed forest (MIXED) & 0.59 & 0.33 & 0.01 \\
\hline & Grassland (GRASS) & $<0.01$ & 0 & 0 \\
\hline & Agricultural cropland (CROP) & 0.01 & 0.15 & 0.59 \\
\hline & Settlements (URBAN) & $<0.01$ & 0.01 & 0.04 \\
\hline & Fine-grained land cover mosaic (MOSAIC) & 0.23 & 0.45 & 0.22 \\
\hline
\end{tabular}

opportunities and threats. The conversations in each focus group were recorded, then transcribed and the themes related to viability of bees, honey products and other ecosystem services, as well as beekeeping as a social activity were extracted. In order to ensure interrater reliability, three of the co-authors read the transcript independently and prepared individual list of themes. We then discussed the individual lists and how the themes should be coded, and produced the complete cumulative list of themes. These themes were then divided into four groups to match social vs. ecological dimensions, and themes that were intrinsic to the local level of bees and beekeepers vs. extrinsic (region, state and international levels). To analyse 
Table 2 PCA scores for the three first principal components explaining the variation among seven land cover types in $5 \times 5 \mathrm{~km}$ grid cells

Extreme values are shown in bold font

\begin{tabular}{lrrr}
\hline Land cover types & \multicolumn{1}{c}{ PC 1 } & \multicolumn{1}{c}{ PC 2 } & \multicolumn{1}{c}{ PC 3 } \\
\hline Coniferous forest (CON) & 0.094 & -0.075 & 0.149 \\
Deciduous forest (DEC) & -0.053 & 0.171 & $\mathbf{0 . 8 0 6}$ \\
Mixed forest (MIXED) & $\mathbf{0 . 7 5 9}$ & -0.288 & -0.255 \\
Grassland (GRASS) & 0.002 & -0.001 & 0.001 \\
Agricultural cropland (CROP) & $-\mathbf{0 . 6 2 3}$ & $-\mathbf{0 . 5 6 1}$ & -0.247 \\
Settlements (URBAN) & -0.027 & 0.002 & -0.005 \\
Fine-grained land cover mosaic (MOSAIC) & -0.152 & $\mathbf{0 . 7 5 3}$ & $-\mathbf{0 . 4 4 9}$ \\
\hline
\end{tabular}

differences among the portfolio of themes divided into social vs. ecological and internal vs. external among the three strata we used Ward's method for hierarchical cluster analyses (Statistica 6.0 by Statsoft).

Social capital is a property of a group or a network. Inspired by Putnam (2001), Szreter and Woolcock (2004) and Agger and Jensen (2015) proposed a conceptual framework for applying social capital to study how public health and area-based initiatives, respectively, can facilitate contact within (bonding social capital), horizontally between networks of actors and stakeholders in an area (bridging social capital), and vertically with external vertical forms of power (linking social capital). These three groups of relations can provide the territorial and spatial planners, and other members of civil society, with necessary access to leveraging resources, ideas and information. Through snowballing we therefore mapped stakeholders among societal sectors (e.g., farmers, local communities, authorities etc.) at multiple levels. This was analysed with beekeepers as local units of bonding social capital through their bridging social capital (trusting relations between those from different other sectorial, demographic and spatial groups) and linking social capital, which focuses on the vertical portfolio of social relationships (Szreter and Woolcock 2004).

For a graphical representation of the interactions among the themes brought up in the focus groups, we applied the fuzzy cognitive mapping (FCM) method (Kosko 1986; Özesmi and Özesmi 2004; Gray et al. 2012, 2015). This illustrates the relationships between the elements of a system, and can be used to compute their strength. Adjacency matrices were built in MS Excel 2016, and analysed using the FCMapper Vs 1.0 package for Excel. Graph networks were generated in Pajek 5.06a. The importance of each theme that emerged from the focus groups in the network is represented by the centrality index (Özesmi and Özesmi 2004). We considered only those themes, which have centrality score above ten.

Ecological system

To capture key aspects of keeping honey bees, we extracted four indicators from the system of honey bee monitoring in Ukraine (Fedoriak et al. 2019), and compiled those using three years of data (2016/2017, 2017/2018, 2018/2019) for each of the three strata 'Traditional' (Putyla district), 'Intermediate' (Storozhynets district) and 'Intensive agriculture' (Khotyn district). The indicators were (1) the rate of winter colony loss, which is used internationally to monitor the survival of managed honey bees (van der Zee et al. 2013); (2) the mean number of apiaries and colonies per beekeeper; (3) the average amount of supplemental feeding of sugar; and (4) the proportion of beekeepers who applied some treatment against Varroa mite. For the first indicator we assessed the occurrences of differences between strata and years by calculating $95 \%$ confidence intervals using quasibinomial generalized linear modelling (GzLM) approach in van der Zee et al. (2013), and for the second and third indicators using Statistica. For the fourth indicator we used $\chi^{2}$ tests.

\section{Results}

Social system

Extraction of themes affecting bees and beekeeping

A total of 33 themes were identified from the 15 focus groups in the three strata (Table 3). While $73 \%$ of the themes concerned social system factors, $27 \%$ 
Table 3 List of all 33 themes brought up by beekeepers in 15 focus groups held in three districts representing the strata in the socialecological gradient captured by Chernivtsi region in Ukraine

\begin{tabular}{|c|c|c|c|c|c|c|c|c|}
\hline \multirow[t]{2}{*}{$\begin{array}{l}\text { Theme's short } \\
\text { name }\end{array}$} & \multirow[t]{2}{*}{$\begin{array}{l}\text { Detailed description of } \\
\text { theme }\end{array}$} & \multicolumn{3}{|l|}{ Stratum } & \multicolumn{4}{|c|}{$\begin{array}{l}\text { Grouping relative to } \\
\text { local beekeepers }\end{array}$} \\
\hline & & $\begin{array}{l}\text { Putyla } \\
\text { district }\end{array}$ & $\begin{array}{l}\text { Storozhynets } \\
\text { district }\end{array}$ & $\begin{array}{l}\text { Khotyn } \\
\text { district }\end{array}$ & $\begin{array}{l}\text { Social } \\
\text { intrinsic }\end{array}$ & $\begin{array}{l}\text { Social } \\
\text { extrinsic }\end{array}$ & $\begin{array}{l}\text { Ecological } \\
\text { intrinsic }\end{array}$ & $\begin{array}{l}\text { Ecological } \\
\text { extrinsic }\end{array}$ \\
\hline $\begin{array}{l}\text { Source of } \\
\text { income }\end{array}$ & $\begin{array}{l}\text { Beekeeping as the main or } \\
\text { additional source of } \\
\text { household income }\end{array}$ & + & + & + & + & & & \\
\hline Satisfaction & $\begin{array}{l}\text { Beekeeping as a hobby, rest, } \\
\text { art, a tool for self- } \\
\text { realization }\end{array}$ & + & + & + & + & & & \\
\hline Naturalness & $\begin{array}{l}\text { A large number of flowering } \\
\text { plants for feeding bee } \\
\text { colonies, stable local } \\
\text { climate, ecologically pure } \\
\text { landscape and insignificant } \\
\text { pesticide loading }\end{array}$ & + & + & + & & & + & \\
\hline $\begin{array}{l}\text { Local } \\
\text { cooperation }\end{array}$ & $\begin{array}{l}\text { Formal and Informal } \\
\text { Cooperation of Beekeepers } \\
\text { (Beekeeping Associations) }\end{array}$ & & + & + & + & & & \\
\hline $\begin{array}{l}\text { Bee product } \\
\text { demand }\end{array}$ & $\begin{array}{l}\text { Increasing demand for bee } \\
\text { products among the } \\
\text { population and increasing } \\
\text { the exportation of honey } \\
\text { and other beekeeping } \\
\text { products }\end{array}$ & + & + & + & & + & & \\
\hline Pollination & $\begin{array}{l}\text { Honey bee provides the } \\
\text { maintenance and operation } \\
\text { of most flowering } \\
\text { ecosystems of the planet by } \\
\text { providing pollination } \\
\text { services }\end{array}$ & & + & + & & & + & \\
\hline $\begin{array}{l}\text { Urban } \\
\text { beekeeping }\end{array}$ & $\begin{array}{l}\text { Some beekeepers are trying } \\
\text { to save their bees from the } \\
\text { detrimental effects of } \\
\text { pesticides by transporting } \\
\text { their apiaries to cities that } \\
\text { are rich in flower beds and } \\
\text { linden alleys }\end{array}$ & & + & + & & & & + \\
\hline $\begin{array}{l}\text { Few } \\
\text { beekeepers }\end{array}$ & $\begin{array}{l}\text { Low density bee apiaries and } \\
\text { lack of pollinators for } \\
\text { crops is beneficial for } \\
\text { increasing the number of } \\
\text { colonies in the region }\end{array}$ & + & & + & + & & & \\
\hline Employment & $\begin{array}{l}\text { In remote villages of the } \\
\text { regional and district } \\
\text { centres of beekeeping } \\
\text { because the economy can } \\
\text { create jobs }\end{array}$ & + & + & + & + & & & \\
\hline Ecofarming & $\begin{array}{l}\text { The use of alternative plant } \\
\text { protection products will } \\
\text { improve the state of } \\
\text { environment and reduce } \\
\text { the loss of bees from } \\
\text { pesticides poisoning }\end{array}$ & + & & + & & & + & \\
\hline
\end{tabular}


Table 3 continued

\begin{tabular}{|c|c|c|c|c|c|c|c|c|}
\hline \multirow[t]{2}{*}{$\begin{array}{l}\text { Theme's short } \\
\text { name }\end{array}$} & \multirow[t]{2}{*}{$\begin{array}{l}\text { Detailed description of } \\
\text { theme }\end{array}$} & \multicolumn{3}{|l|}{ Stratum } & \multicolumn{4}{|c|}{$\begin{array}{l}\text { Grouping relative to } \\
\text { local beekeepers }\end{array}$} \\
\hline & & $\begin{array}{l}\text { Putyla } \\
\text { district }\end{array}$ & $\begin{array}{l}\text { Storozhynets } \\
\text { district }\end{array}$ & $\begin{array}{l}\text { Khotyn } \\
\text { district }\end{array}$ & $\begin{array}{l}\text { Social } \\
\text { intrinsic }\end{array}$ & $\begin{array}{l}\text { Social } \\
\text { extrinsic }\end{array}$ & $\begin{array}{l}\text { Ecological } \\
\text { intrinsic }\end{array}$ & $\begin{array}{l}\text { Ecological } \\
\text { extrinsic }\end{array}$ \\
\hline Apitherapy & $\begin{array}{l}\text { Traditional medicine uses } \\
\text { bee products for the } \\
\text { treatment of various } \\
\text { diseases }\end{array}$ & + & + & + & + & & & \\
\hline Parenting & $\begin{array}{l}\text { Involving children in } \\
\text { beekeeping has a positive } \\
\text { effect on their psycho- } \\
\text { emotional health and } \\
\text { educates a careful attitude } \\
\text { to nature }\end{array}$ & + & & & + & & & \\
\hline Unique honey & $\begin{array}{l}\text { Production of rare varieties } \\
\text { of honey with high flavour, } \\
\text { aromatic and healing } \\
\text { properties }\end{array}$ & + & & & & & + & \\
\hline $\begin{array}{l}\text { Multilevel } \\
\text { governance }\end{array}$ & $\begin{array}{l}\text { Due to the association of } \\
\text { beekeepers in civic } \\
\text { organizations, they can, at } \\
\text { the district or state level, } \\
\text { influence the legislation to } \\
\text { improve the beekeeping } \\
\text { industry in general }\end{array}$ & & & + & & + & & \\
\hline Native bees & $\begin{array}{l}\text { Aboriginal bees } \\
\text { evolutionarily adapted to } \\
\text { local environmental } \\
\text { conditions and use local } \\
\text { resources in the best way, } \\
\text { unlike intruded species of } \\
\text { bees }\end{array}$ & + & + & & & & + & \\
\hline $\begin{array}{l}\text { Pesticide } \\
\text { escalation }\end{array}$ & $\begin{array}{l}\text { The use of pesticides results } \\
\text { in large scale loss of bee } \\
\text { colonies by increasing the } \\
\text { resistance of pests to } \\
\text { pesticides and leading to } \\
\text { the use of new stronger and } \\
\text { more unsafe }\end{array}$ & + & + & + & + & & & \\
\hline $\begin{array}{c}\text { Counterfeit } \\
\text { pesticides }\end{array}$ & $\begin{array}{l}\text { Counterfeit pesticides make } \\
\text { up to } 25 \% \text { on Ukrainian } \\
\text { market and a considered to } \\
\text { be major threats in } \\
\text { agroecosystems and } \\
\text { surrounding semi-natural } \\
\text { habitats }\end{array}$ & + & + & + & & + & & \\
\hline $\begin{array}{l}\text { Uncontrolled } \\
\text { pesticides } \\
\text { use }\end{array}$ & $\begin{array}{l}\text { There is no control over the } \\
\text { use of pesticides and } \\
\text { compliance mechanisms in } \\
\text { agriculture }\end{array}$ & & + & + & & + & & \\
\hline $\begin{array}{l}\text { Uncontrolled } \\
\text { pesticide } \\
\text { trade }\end{array}$ & $\begin{array}{l}\text { The problem with entering } \\
\text { the Ukrainian markets of } \\
\text { counterfeit and prohibited } \\
\text { pesticides }\end{array}$ & & & + & & + & & \\
\hline
\end{tabular}


Table 3 continued

\begin{tabular}{|c|c|c|c|c|c|c|c|c|}
\hline \multirow[t]{2}{*}{$\begin{array}{l}\text { Theme's short } \\
\text { name }\end{array}$} & \multirow[t]{2}{*}{$\begin{array}{l}\text { Detailed description of } \\
\text { theme }\end{array}$} & \multicolumn{3}{|l|}{ Stratum } & \multicolumn{4}{|c|}{$\begin{array}{l}\text { Grouping relative to } \\
\text { local beekeepers }\end{array}$} \\
\hline & & $\begin{array}{l}\text { Putyla } \\
\text { district }\end{array}$ & $\begin{array}{l}\text { Storozhynets } \\
\text { district }\end{array}$ & $\begin{array}{l}\text { Khotyn } \\
\text { district }\end{array}$ & $\begin{array}{l}\text { Social } \\
\text { intrinsic }\end{array}$ & $\begin{array}{l}\text { Social } \\
\text { extrinsic }\end{array}$ & $\begin{array}{l}\text { Ecological } \\
\text { intrinsic }\end{array}$ & $\begin{array}{l}\text { Ecological } \\
\text { extrinsic }\end{array}$ \\
\hline $\begin{array}{l}\text { Chinese } \\
\text { competition }\end{array}$ & $\begin{array}{l}\text { Cheap non-quality Chinese } \\
\text { honey and counterfeit } \\
\text { honey falling into store } \\
\text { shelves leads to problems } \\
\text { of selling local beekeepers } \\
\text { products }\end{array}$ & + & & + & & + & & \\
\hline $\begin{array}{l}\text { Beekeeper- } \\
\text { farmer } \\
\text { conflict }\end{array}$ & $\begin{array}{l}\text { Aggravation of the conflict } \\
\text { through poisoning of bees } \\
\text { and damage to property of } \\
\text { farmers, difficulties arise in } \\
\text { resolving the conflict }\end{array}$ & & & + & + & & & \\
\hline $\begin{array}{l}\text { Loss of skilled } \\
\text { beekeepers }\end{array}$ & $\begin{array}{l}\text { From the old generation } \\
\text { beekeeper's point of view } \\
\text { the experienced beekeepers } \\
\text { are the most skilful }\end{array}$ & & & + & + & & & \\
\hline High cost & $\begin{array}{l}\text { High costs of keeping a bee } \\
\text { farm and low profitability }\end{array}$ & + & + & + & + & & & \\
\hline $\begin{array}{l}\text { Low product } \\
\text { price }\end{array}$ & $\begin{array}{l}\text { The presence of counterfeit } \\
\text { and cheap Chinese honey } \\
\text { in the market, together } \\
\text { with the unstable economic } \\
\text { situation in the country, } \\
\text { leads to higher costs and a } \\
\text { low price for beekeeping } \\
\text { products }\end{array}$ & & & + & & + & & \\
\hline $\begin{array}{l}\text { No state } \\
\text { support }\end{array}$ & $\begin{array}{l}\text { The lack of subsidies for } \\
\text { beekeeping and the } \\
\text { imperfection of the laws in } \\
\text { the industry }\end{array}$ & + & + & + & & + & & \\
\hline $\begin{array}{l}\text { Intensified } \\
\text { agriculture }\end{array}$ & $\begin{array}{l}\text { Intensification of the } \\
\text { agrarian sector leads to an } \\
\text { increase in pesticide } \\
\text { loading and monoculture } \\
\text { growth along with a } \\
\text { decrease in biodiversity }\end{array}$ & & + & + & & + & & \\
\hline $\begin{array}{r}\text { Bee food } \\
\text { decline }\end{array}$ & $\begin{array}{l}\text { Loss of natural land covers } \\
\text { and intensification of } \\
\text { agrarian production leads } \\
\text { to the depletion of forage } \\
\text { resources of bees }\end{array}$ & + & + & + & & & + & \\
\hline $\begin{array}{l}\text { Too many } \\
\text { beekeepers }\end{array}$ & $\begin{array}{l}\text { The high density of bee } \\
\text { colonies leads to the } \\
\text { depletion of feed resources } \\
\text { of this local environment }\end{array}$ & & + & & + & & & \\
\hline $\begin{array}{l}\text { Climate } \\
\text { change }\end{array}$ & $\begin{array}{l}\text { Droughts, unstable winters, } \\
\text { moving the terms of } \\
\text { flowering leads to stress in } \\
\text { bee colonies and requires } \\
\text { them to adapt to rapid } \\
\text { climate change }\end{array}$ & + & + & & & & & + \\
\hline
\end{tabular}


Table 3 continued

\begin{tabular}{|c|c|c|c|c|c|c|c|c|}
\hline \multirow[t]{2}{*}{$\begin{array}{l}\text { Theme's short } \\
\text { name }\end{array}$} & \multirow[t]{2}{*}{$\begin{array}{l}\text { Detailed description of } \\
\text { theme }\end{array}$} & \multicolumn{3}{|l|}{ Stratum } & \multicolumn{4}{|c|}{$\begin{array}{l}\text { Grouping relative to } \\
\text { local beekeepers }\end{array}$} \\
\hline & & $\begin{array}{l}\text { Putyla } \\
\text { district }\end{array}$ & $\begin{array}{l}\text { Storozhynets } \\
\text { district }\end{array}$ & $\begin{array}{l}\text { Khotyn } \\
\text { district }\end{array}$ & $\begin{array}{l}\text { Social } \\
\text { intrinsic }\end{array}$ & $\begin{array}{l}\text { Social } \\
\text { extrinsic }\end{array}$ & $\begin{array}{l}\text { Ecological } \\
\text { intrinsic }\end{array}$ & $\begin{array}{l}\text { Ecological } \\
\text { extrinsic }\end{array}$ \\
\hline $\begin{array}{l}\text { Invasive } \\
\text { species }\end{array}$ & $\begin{array}{l}\text { Invasive species such as } \\
\text { Varroa destructor, and } \\
\text { potentially Vespa velutina } \\
\text { and Aethina tumida causes } \\
\text { concern to beekeepers }\end{array}$ & + & + & & & & & + \\
\hline $\begin{array}{l}\text { Fake anti- } \\
\text { varroa } \\
\text { products }\end{array}$ & $\begin{array}{l}\text { The resistance of Varroa } \\
\text { destructor and the presence } \\
\text { of falsification leads to } \\
\text { problems in the treatment } \\
\text { of varroosis }\end{array}$ & & + & & & + & & \\
\hline $\begin{array}{l}\text { Import of bee } \\
\text { breeds }\end{array}$ & $\begin{array}{l}\text { In Ukraine there is no } \\
\text { control over the import of } \\
\text { new species of bees }\end{array}$ & + & + & & & + & & \\
\hline $\begin{array}{l}\text { Unsafe } \\
\text { innovations }\end{array}$ & $\begin{array}{l}\text { Borrowing negative } \\
\text { experiences from EU }\end{array}$ & & & + & & + & & \\
\hline Sum & & 20 & 22 & 25 & 12 & 12 & 6 & 3 \\
\hline
\end{tabular}

Short theme names in bold are those 17 themes that were mentioned in more than $25 \%$ (i.e. 4 to 12 times) of the 15 focus groups

Table 4 Distribution of the 33 themes identified by beekeepers and distributed among social and ecological system components (columns), and between intrinsic local level and scale vs. extrinsic higher levels of governance and larger spatial extents (rows)

\begin{tabular}{|c|c|c|}
\hline & Social system & Ecological system \\
\hline $\begin{array}{l}\text { Extrinsic to case study } \\
\text { (regional, national, } \\
\text { international levels) }\end{array}$ & $\begin{array}{l}12 \text { themes in total: } \\
\text { Bee product demand, Multilevel governance, Counterfeit } \\
\text { pesticides, Uncontrolled pesticides use, Uncontrolled } \\
\text { pesticides trade, Chinese competition, Low product price, } \\
\text { No state support, Intensified agriculture, Fake anti- } \\
\text { varroa products, Import of bee breeds, Unsafe innovations }\end{array}$ & $\begin{array}{l}3 \text { themes in total: } \\
\text { Urban beekeeping, Climate change, } \\
\text { Invasive species }\end{array}$ \\
\hline $\begin{array}{l}\text { Intrinsic to case study area } \\
\text { (individual focus group) }\end{array}$ & $\begin{array}{l}12 \text { themes in total: } \\
\text { Source of income, Satisfaction, Local cooperation, Few } \\
\text { beekeepers, Employment, Apitherapy, Parenting, } \\
\text { Pesticide escalation, Beekeeper-farmer conflict, Loss of } \\
\text { skilled beekeepers, High cost, Too many beekeepers }\end{array}$ & $\begin{array}{l}6 \text { themes in total: } \\
\text { Naturalness, Pollination, Ecofarming, } \\
\text { Unique honey, Native bees, Bee food } \\
\text { decline }\end{array}$ \\
\hline
\end{tabular}

Bold themes represent mentioning in 4 to 12 of 15 focus groups (see also Table 3 )

concerned ecological system factors (Table 4). For social system factors the same number of factors (12) was intrinsic and extrinsic, respectively. For ecosystem factors two-thirds $(n=9)$ were intrinsic to the local level. The 33 different themes were found in 0-12 of the 15 focus groups (Fig. 4).

Next, by means of hierarchical cluster analysis, we analysed for differences among the portfolios of themes among the three strata divided into social vs. ecological and internal vs. external. Regarding factors relating to the social system and intrinsic to the local level, the focus groups from 'Traditional' stratum showed higher similarity, while the focus groups from both 'Intermediate' and 'Intensive agriculture' strata formed one big heterogeneous cluster (Fig. 5). Concerning the portfolio of factors relating to the extrinsic 

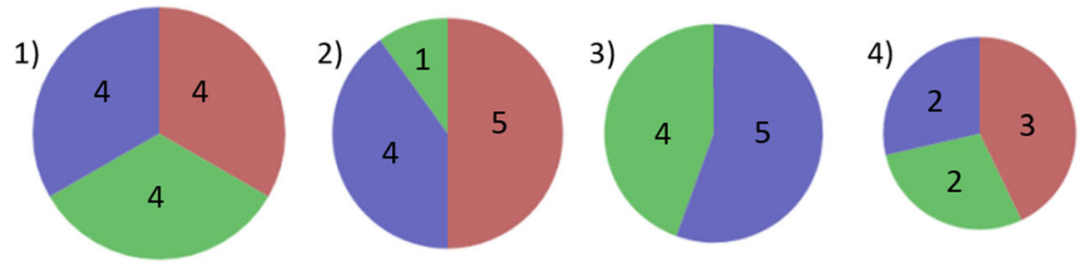

1) Satisfaction

5)

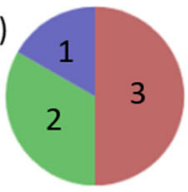

\section{6)}

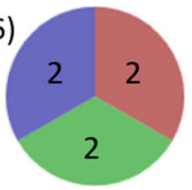

8)

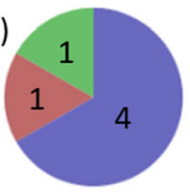

13)

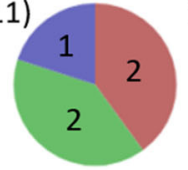

12)
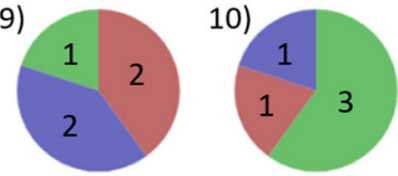

14)

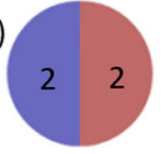

15)

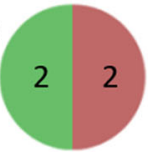

16)

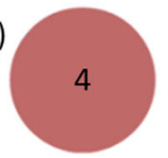

17)

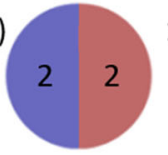

18)

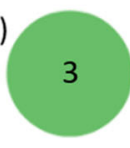

19)
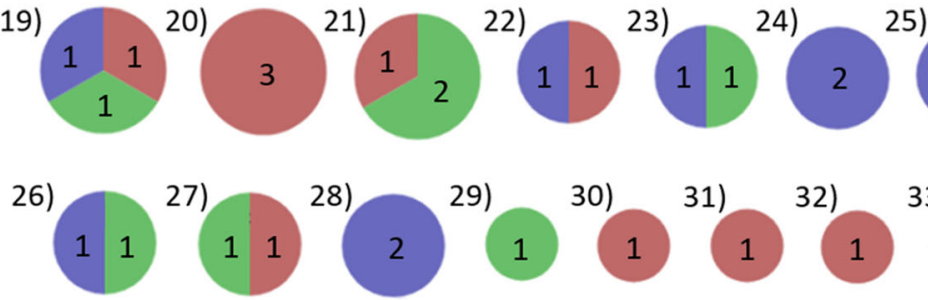

29)

30)

31)

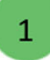

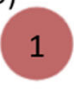

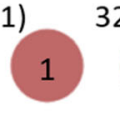

32)

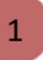

33)

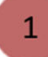

2) Pesticide escalation

3) Climate change

4) Source of income

5) No state support

6) Naturalness

7) Native bees

8) Bee food decline

9) Counterfeit pesticides

10) Bee product demand

11) Employment

12) Apitherapy

13) Uncontrolled pesticides USE

14) Intensified agriculture

15) Ecofarming

16) Beekeeper-farmer conflict

17) Local cooperation

18) Unique honey

19) High cost

20) Uncontrolled pesticide TRADE

21) Chinese competition

22) Urban beekeeping

23) Import of bee breeds

24) Fake anti-varroa products

25) Pollination

26) Invasive species

27) Few beekeepers

28) Too many beekeepers

29) Parenting

30) Multilevel governance

31) Low product price

32) Unsafe innovations

33) Loss of skilled beekeepers
Fig. 4 Illustration of the number of focus groups, ranging from one to 12 , in which a particular theme $(\mathrm{n}=33)$ was mentioned. The three districts 'Traditional' Putyla, 'Intermediate' Storozhynets and 'Intensive agriculture' Khotyn in Chernivtsi

social system three of five focus groups representing the 'Intensive agriculture' stratum and one from the 'Intermediate' stratum formed the small cluster, while the large cluster was a heterogeneous mixture of the remaining 11 focus groups. Thus, the beekeepers from both extremes of the gradient sampled had a tendency to concentrate on particular issues, e.g., obstacles in selling honey in the 'Traditional' stratum or fake honey and pesticides in the 'Intensive agriculture' stratum. The beekeepers from the 'Intermediate' stratum referred to all those mentioned above. Regarding factors relating to the ecological system intrinsic to the local level, particular focus groups within the three strata had the highest similarity region are shown in green, blue and red, respectively. For the analyses of interactions between factors (see Fig. 6), only those mentioned $>25 \%(>3)$ of the focus groups were included

reflecting local ecological concerns, while in general there was no clear separation among strata. Concerning the portfolio of factors extrinsic to the local ecological system there were only three themes to analyse. The two main clusters obtained included (1) four focus groups from the 'Intensive agriculture' strata and one from the 'Traditional', and (2) three focus groups from the two other strata. Thus, the cluster analysis confirmed the gradient.

For those 17 themes that were mentioned in more than $25 \%$ of 15 focus groups (Table 3), using fuzzy cognitive mapping (FCM), we also analysed the positive and negative factors among the themes for each stratum. We used the obtained data to build 

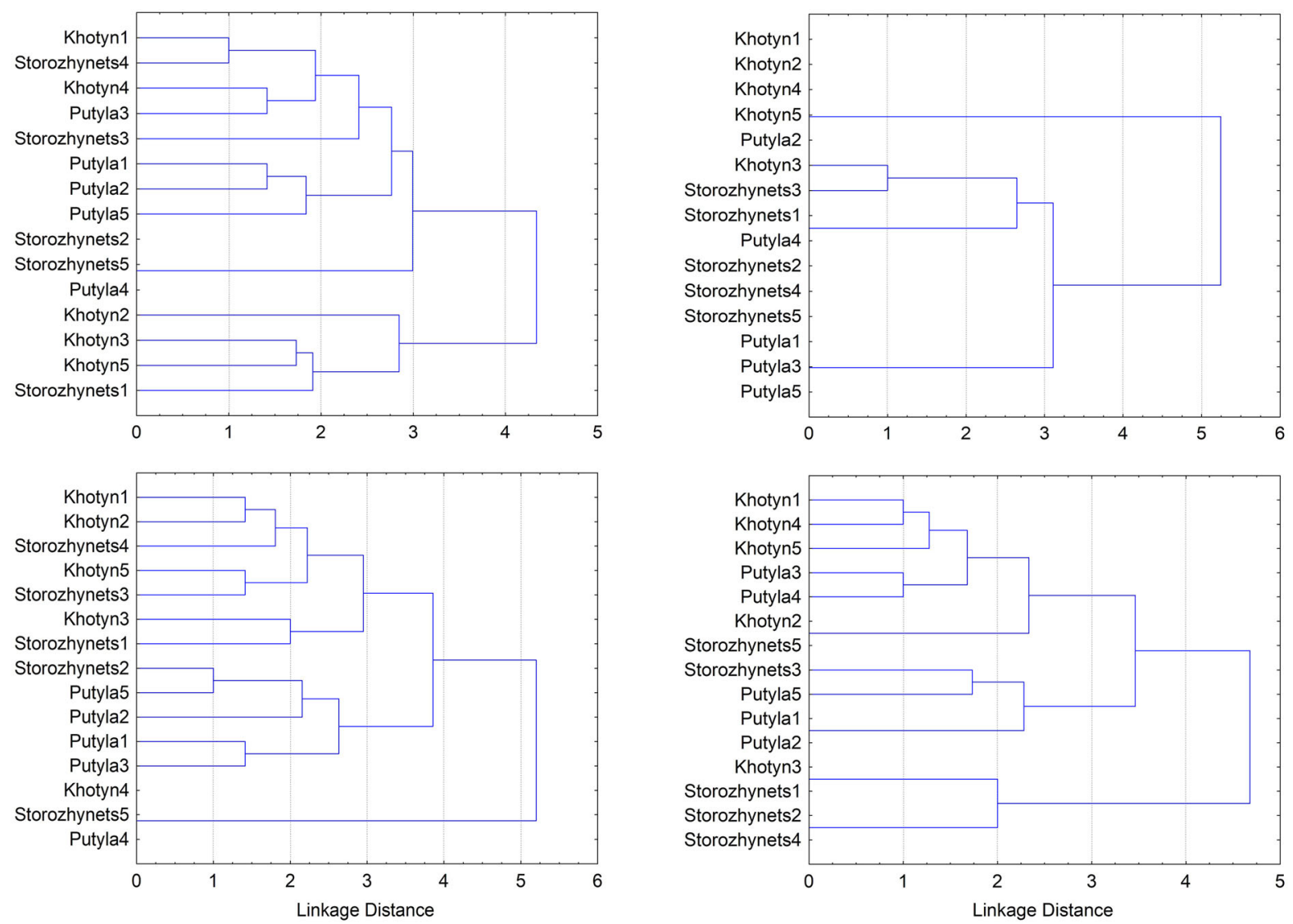

Fig. 5 Similarity of the focus groups in the three strata based on the 33 themes mentioned (Table 3, Fig. 4). Dendrograms were made using Ward's method. For each of three districts, viz. 'Traditional' Putyla, 'Intermediate' Storozhynets and 'Intensive

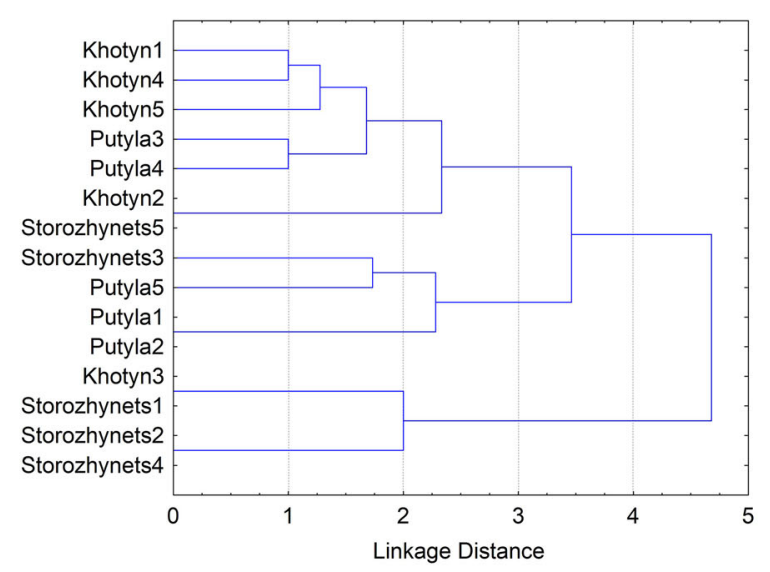

agriculture' Khotyn, the themes were divided into four combinations of social (to the left) vs. ecological (to the right) dimensions, and internal to the focus group (bottom row) vs. external to it (top row) (see Table 4)

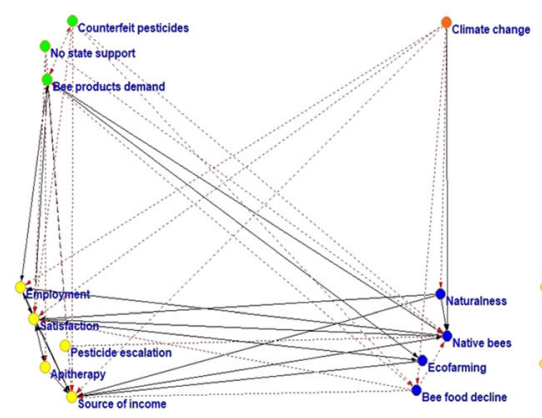

Fig. 6 Interactions among themes brought up by beekeepers in focus groups made in 'Traditional' Putyla (left), 'Intermediate' Storozhynets (centre), 'Intensive agriculture' Khotyn (right) in Ukraine's Chernivtsi region. The graphs represent the 17 most common themes of 33 (Table 3). For each graph the themes are

adjacency matrices and corresponding network graphs for the 'Traditional' stratum (Putyla), the
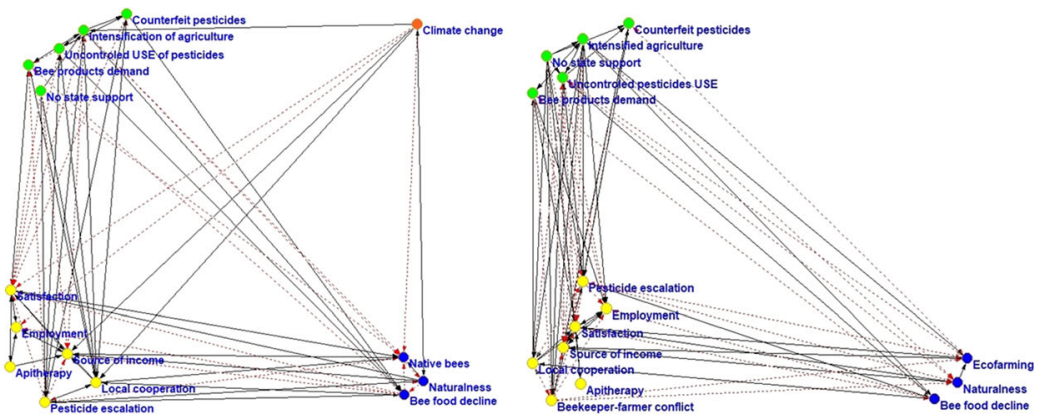

divided into four combinations of social (to the left) vs. ecological (to the right) dimensions, and internal to the focus group (bottom row) vs. external to it (top row). Lines denote positive relationships and dotted lines negative relationships

'Intermediate' stratum (Storozhynets), and the 'Intensive agriculture' stratum (Khotyn) (Fig. 6). In the 
'Traditional' stratum we found 13 factors linked by 48 connections (13/48), in the 'Intermediate' stratum the corresponding numbers were $15 / 83$, and in the 'Intensive agriculture' stratum 15/90, respectively. Analysis of each of the three strata's networks in detail showed that most of the discussed themes were included in the FCM models for all three strata. We found the theme 'No state support' to be a common driver component for all the three networks. It was the only strong driver component both in 'Intermediate' and 'Intensive agriculture' strata, but in the 'Traditional' stratum it was equally important with two more driver components: 'Climate change' and 'Pesticide escalation'. No receiver component was detected (Fig. 6).

Focusing on those themes, which have centrality score above ten, we found the following. For 'Traditional' Putyla the highest individual weights were 'Satisfaction' (16), 'Source of income' (14) and 'Native bees' (11); for 'Intermediate' Storozhynets 'Satisfaction' (20), 'Pesticide escalation' (18), 'Intensification of agriculture' (16), 'Local cooperation' (16), 'Source of income' (13), 'Bee food decline' (13), 'Counterfeit pesticides' (11), 'Bee products demand' (11), 'Native bees' (10). In 'Intensive agriculture' Khotyn we detected nine themes with a high centrality score 'Pesticide escalation' (20), 'Satisfaction' (19), 'Uncontrolled use of pesticides' (15), 'Intensification of agriculture' (15),
'Miscommunication between beekeepers and farmers' (14), 'Ecofarming' (13), 'Local cooperation' (13), 'Employment' (12), 'Source of income' (12).

The relationships between the separate themes are complicated, and can have both positive and negative effects on each other. For instance, intensification of agriculture has positive impact on pesticide escalation, but also ecofarming as a means of environmental mitigation. The main positive effect of ecofarming is increasing of bee products demand and thus of household income. Pesticide escalation has negative impact on all ecological factors, but has a positive impact on the level of local cooperation. Weak system of state support has negative impact on native bees. Simultaneously it has positive impact on local cooperation that leads to supporting native bees. In total local cooperation is stronger in cases when other social factors are weak. 'Satisfaction', 'Source of income' and 'Employment' are common for all three strata, and have positive impacts on all others.

\section{Stakeholder mapping}

Dividing the stakeholder types mentioned in the focus groups among sectors and levels of governance we found that in the 'Intensive agriculture' stratum all sectors and levels of governance were mentioned. This shows that beekeepers as local units of bonding social capital possess bridging social capital (trusting

Table 5 Stakeholder groups and their distribution among levels of governance (rows) and sectors including academia (columns)

\begin{tabular}{|c|c|c|c|c|c|}
\hline & & Civil sector & Public sector & Private sector & Academia \\
\hline \multirow[t]{4}{*}{ Putyla } & International & Tourists & $\mathrm{EU}$ & & \\
\hline & Ukraine & & Government officials & & \\
\hline & Region & & District government & & Bee monitoring \\
\hline & Local & & & & \\
\hline \multirow[t]{4}{*}{ Storozhynets } & International & & EU & & \\
\hline & Ukraine & & Government officials & & $\begin{array}{l}\text { Institute of } \\
\text { beekeeping }\end{array}$ \\
\hline & Region & & & & Bee monitoring \\
\hline & Local & & & & \\
\hline \multirow[t]{4}{*}{ Khotyn } & International & & & European buyers & Bee monitoring \\
\hline & Ukraine & & & Exporters & Bee monitoring \\
\hline & Region & & $\begin{array}{l}\text { State service on food } \\
\text { safety }\end{array}$ & $\begin{array}{l}\text { Buyers of bee } \\
\text { packages }\end{array}$ & Bee monitoring \\
\hline & Local & $\begin{array}{l}\text { Local territorial } \\
\text { communities }\end{array}$ & & Farmers & \\
\hline
\end{tabular}


relations between those from different other sectorial, demographic and spatial groups) as well as linking social capital focusing on the vertical portfolio of social relationships. In contrast, the portfolios for the other two strata were incomplete (Table 5); in both strata private sector was missing, and in the 'Intermediate' stratum neither civil sector nor local level were mentioned. Hence both bridging and linking forms of social capitals were not well developed.

\section{Ecological system: honey bee colony losses}

The honey bee colony loss rates in all the three investigated winters were significantly higher (no overlap between $95 \%$ CIs) in the remote mountain stratum Putyla compared to the 'Intensive agriculture' stratum Khotyn (Fig. 7). In spite of the more natural conditions in the remote mountain region the winter loss rates for 2016/17, 2017/18, 2018/19, were 15-22\% compared to $8-14 \%$ in the 'Intensive agriculture' stratum. The 'Intermediate' stratum loss rates were $6-14 \%$. The number of apiaries cared for by each beekeeper varied between one and five, and did not depend on landscape stratum or year, thus we can conclude that average number of apiaries per beekeeper in Chernivtsi region is 1.2. The number of colonies per beekeeper before wintering varied

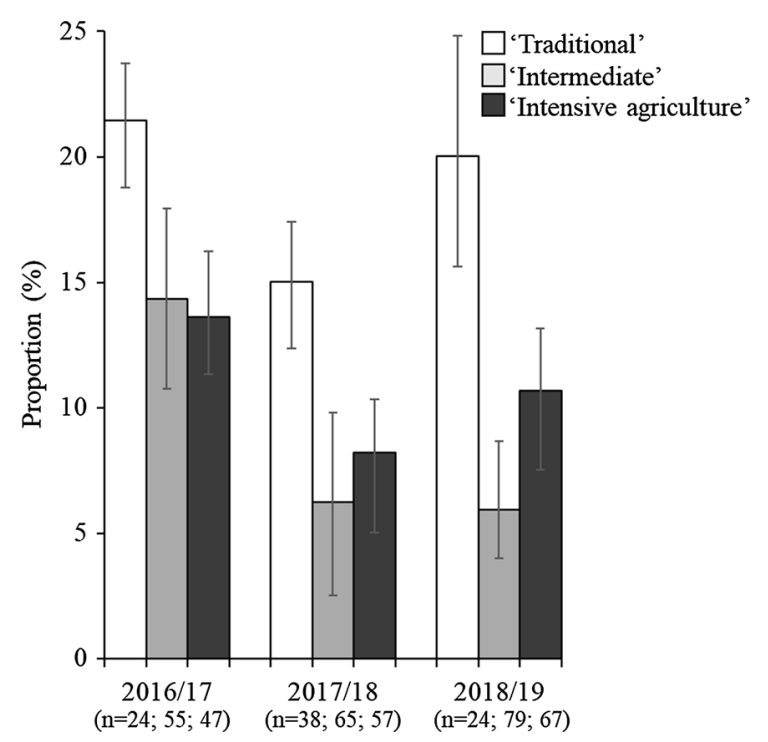

Fig. 7 The overall winter loss rate of honey bee colonies in Chernivtsi region, Ukraine. The number of responding beekeepers (n) is shown for each stratum and year. Error bars denote $95 \%$ confidence intervals widely: 2-76 in the 'Traditional' stratum, 2-300 in the 'Intermediate' stratum, and 1-440 in the 'Intensive

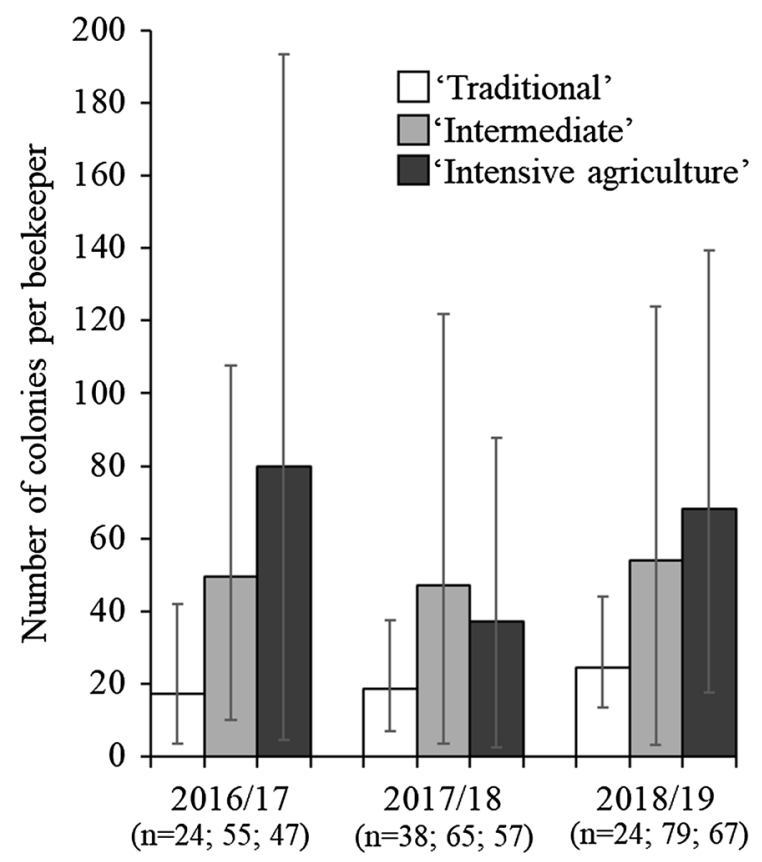

Fig. 8 The average number of colonies per beekeeper in three landscape strata in Chernivtsi region, Ukraine. The number of responding beekeepers (n) is shown for each stratum and year. Error bars denote $95 \%$ confidence intervals

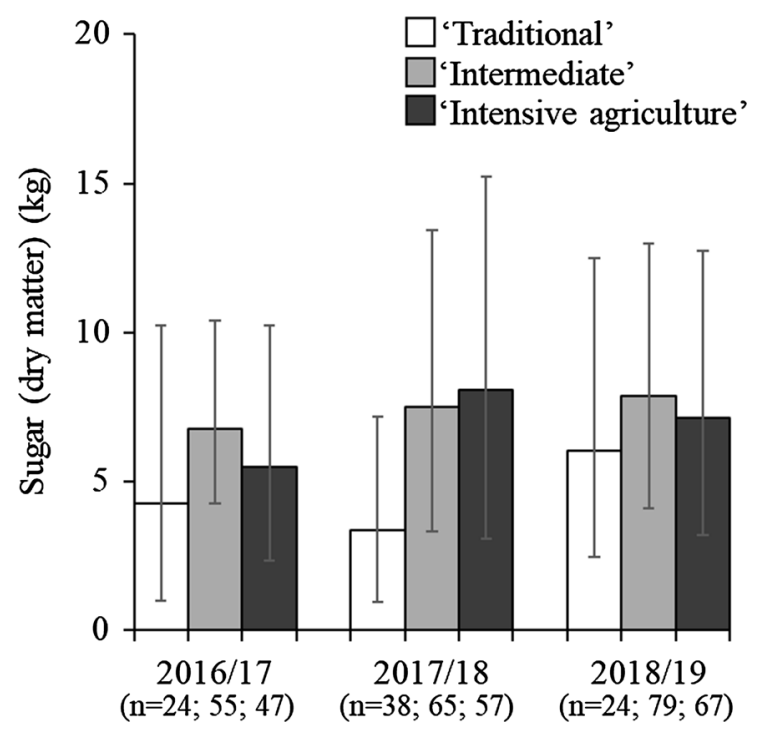

Fig. 9 The average amount of supplemental feeding of sugar (dry matter) used by the beekeepers in three landscape strata of Chernivtsi region, Ukraine. The number of responding beekeepers (n) is shown for each stratum and year. Error bars denote $95 \%$ confidence intervals 


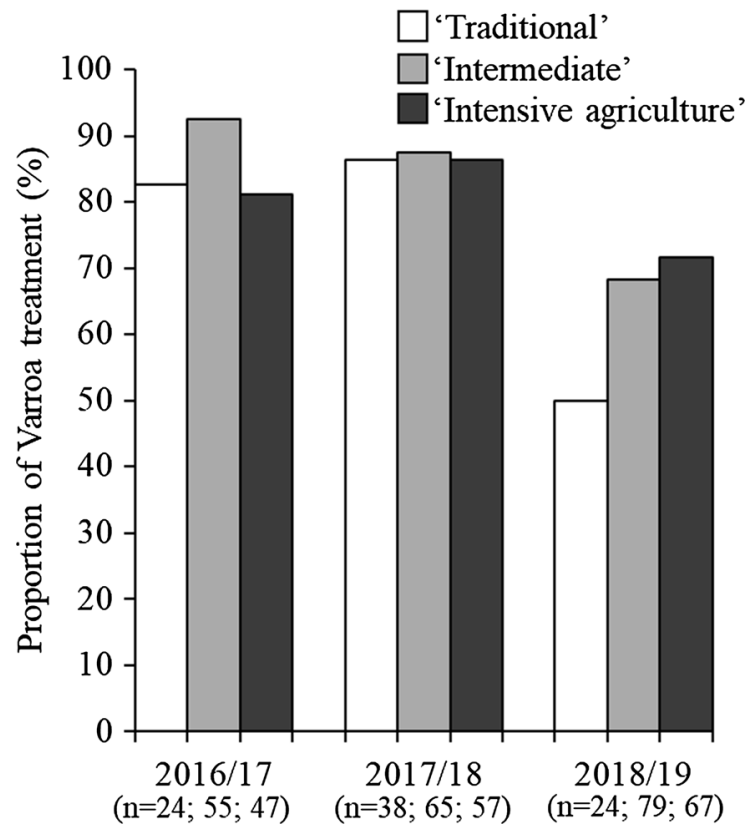

Fig. 10 Proportion of beekeepers of Chernivtsi region, Ukraine who apply any treatment against Varroa mites. The number of responding beekeepers (n) is shown for each stratum and year

agriculture' stratum. There were no statistically significant differences neither among strata nor among years (Fig. 8). Sugar feeding was used as a supplement in all three regions. The average amount of sugar supplied per colony varied between 3.35 and $8.05 \mathrm{~kg}$, without spatial and temporal differences (Fig. 9). Finally, the proportion of beekeepers who applied some kind of treatment against Varroa mite was always $>50 \%$, but not different among the three strata for any of the 3 years (Fig. 10; $\chi^{2}=3.3$, $\left.\mathrm{p}=0.19 ; \chi^{2}=0.08, \mathrm{p}=0.96 ; \chi^{2}=3.86, \mathrm{p}=0.14\right)$.

\section{Discussion}

Are both ecological and social factors important for colony losses?

Like any of nature's benefits to people (Pascual et al. 2017), ecosystem services derived from bees are affected by factors in both ecological and social systems. However, monitoring and research on beekeeping and bee health in Europe focus on ecological aspects (e.g., Brodschneider et al. 2018; Gray et al. 2019). This study highlights the need to add a social system perspective in terms of beekeeper practices and skills, and collaborative capacity. Horizon scanning through focus groups is a tool to do that by gathering, processing and disseminating information to support decision-making in the future (e.g., Shackleton et al. 2017; Sutherland and Woodroof 2009; Bengston 2013). A horizon scanning is both an approach to begin the process of knowledge production and learning with practitioners, and to interpret and discuss the results from research. For managed honey bee colonies the key practitioner is the beekeeper. The main factors sustaining honey bee colonies are beekeepers' background and practices (Jacques et al. 2017).

According to Flyvbjerg (2001, p. 60) a key role of social science is"...to carry out analyses and interpretations of the status of values and interests in society aimed at social commentary and social action, i.e. praxis...". This can be addressed through three questions to those who are involved with praxis, for example beekeepers: Where are we going? Is this desirable? What should be done? In this study the focus group approach to horizon scanning addresses those kinds of questions, and analyses how they are connected. This social science approach was complemented with analyses of honey bee colony losses and a set of factors affecting this.

Lack of nectar and pollen producing flowers is known to be one of the drivers of bee decline (Goulson et al. 2015). van der Zee et al. (2013) suggested that presence of oilseed rape or maize might also be indicative of a lack of diversity of forage, which could have detrimental effects on honey bee colonies. Agricultural crops are also expected to contain agricultural chemicals that may have negative effects on honey bees, including favouring the diffusion of bee diseases by sub-lethal doses of immunosuppressive pesticides and contributing to stress-induced colony losses (Sánchez-Bayo et al. 2016). This is especially relevant for Ukraine, which is known for intense and uncontrolled use of pesticides, including high percentage of fake-labelled (Lycholat 2018), severe summer losses of bees as a result of poisoning happen regularly (e.g., Anon. 2018). In a recent international study by Gray et al. (2019) of the relative colony loss rates, beekeepers reported whether or not their honey bees had access to orchards, oilseed rape, maize, sunflower, heather and autumn forage crops (intended as melliferous plants growing on land lying fallow). 
The results indicated that for all these plant sources except sunflower, beekeepers responding "No" had significantly lower losses than those responding "Yes" or "Don't know". However, the results varied greatly between countries. For example, for orchards, "No" usually corresponded to the lower loss rate, with an exception for Portugal. For oilseed rape, for Finland, Scotland, Serbia and Ukraine "Yes" responders had a lower loss rate than respondents who answered "No", while in Austria, France and Germany the outcome was the opposite (Gray et al. 2019).

Our results from the Ukrainian case study show that the hypothesis that bee colony losses should be higher in an intensively managed agricultural landscape compared to a traditional cultural landscape could be rejected. The reason is that during all 3 years the pattern was the opposite. Analysing the ecological system, all the three strata have not only different landscape characteristics at district and bee foraging scales (Table 1) and cultural traditions, but also different climatic conditions, as well as nectar and pollen food conditions for honey bees. Winters in the highlands of the 'Traditional' stratum are longer and colder with higher amount of snow (Table 1). Therefore, the risk of colony mortality as a result of suffocation at high snow cover and/or starvation is higher. On the other hand, in the lowland 'Intensive agriculture' Khotyn stratum the daily air temperature amplitudes are wider, causing difficulties for wintering bees as night frosts are often followed by thaws (Gerenchuk 1978; Sarchynska 2017).

Rather, the results from the focus groups suggest a social system hypothesis for the observed pattern. Governance and management of natural resources can be characterised as good if evidence-based knowledge is good and stakeholder engagement is broad across sectors and societal levels (e.g., Lee 1993). In fact, most (73\%) of the 33 beekeeping themes identified by beekeepers concerned the social system. In this study, the richness of themes brought up by beekeepers in the focus groups (Table 3), and the number of stakeholders mentioned (Table 5), were higher in the 'Intensive agriculture' stratum compared to the 'Traditional' stratum ( 25 vs. 20 , respectively, Table $3 ; 9$ vs. 5, respectively, Table 5). This suggests that beekeepers' knowledge about honey bee management, and about their social-ecological system, affects the level of honey bee colony losses, which is consistent with results recently presented by Oberreiter and
Brodschneider (2020). This requires systems analyses of honey bees and beekeeping. The fuzzy cognitive mapping approach allows the discovery of characteristic patterns of interaction among the themes brought up by beekeepers. Three examples from our three strata are the following.

In the remote 'Traditional' stratum (Putyla) the following linkages (marked with an arrow) were observed: "naturalness" $\rightarrow$ "native bees" $\rightarrow$ " unique honey" $\rightarrow$ "source of income" $\rightarrow$ "employment". Thus, in beekeepers' opinion their aboriginal bees, which are evolutionarily adapted to use local resources, ensure unique honey of the high quality and taste. Naturalness of the landscape attracts customers, helps to promote the products, which results in stable income. In the 'Intermediate' Storozhynets the linkages were "no state support $\rightarrow$ "uncontrolled pesticide trade" $\rightarrow$ "counterfeit pesticides" $\rightarrow$ "urban beekeeping". This implies that beekeepers think that rural beekeeping tends to decay because state control of pesticide trade and quality is inefficient. This promotes development of beekeeping in urban environments. Finally, for the 'Intensive agriculture' stratum the linkages were "miscommunication between beekeepers and farmers" $\rightarrow$ "pesticide escalation" $\rightarrow$ "uncontrolled pesticide use" $\rightarrow$ "beekeeper-farmer conflict". Thus, keeping their bees in a landscape with severe dominance of agricultural land (Table 1) with uncontrolled pesticide use (Lycholat 2018), beekeepers in this stratum suffer poisoning of bees regularly (e.g., Anon. 2018). This provokes severe beekeeper-farmer conflicts, including strikes with road closures, and deliberate damage to agricultural machinery.

Given its large size, diversity of ecoregions, and diverse types of SES, Ukraine is well suited for analyses of the effects of temporal and spatial as well as socio-economic factors on bee well-being and beekeeping. Comparative studies with other beehuman resource systems (e.g., Patel et al. 2020) using the SES framework would also be valuable.

\section{Beekeeping as a social innovation supporting rural} development

A general trend in Europe is that new inhabitants and new kinds of jobs in rural areas are no longer provided by traditional sectors such as agriculture and forestry aimed at wood and biomass production only (e.g., 
André 1998; MacDonald et al. 2000). This leads to migration from rural to urban areas within countries (e.g., Keuschnigg et al. 2019 about Sweden; Burneika et al. 2014 and Ubareviciene; Van Ham 2017 about Lithuania). Countries in transition are particularly vulnerable. For example, Ukraine has experienced a sustained demographic crisis since independence in 1991. In a European context Ukraine demonstrates an unprecedented negative natural increase (Skryzhevska and Karacsonyi 2012). Ukraine's population declined from 52 million in 1990, 45 million in 2013 and 42 million in 2018, fertility remains far below replacement, and emigration is still of concern (Romaniuk and Gladun 2015; State Statistics Service of Ukraine 2018). Rural areas are particularly vulnerable, but the decline process can sometimes be balanced through amenity migration (Niedomysl 2008), retirement (Lundholm 2012), nature- and culture based tourism focused on wilderness and biodiversity (Sievänen et al. 2013), and attracting new inhabitants by valuable nature and cultural landscapes (Eimermann 2015). In response to rural decline in Ukraine, Skryzhevska and Karacsonyi (2012) recommended that governmental policies should aim at improving economic and social well-being in rural landscapes.

In our study, the theme 'No state support' was mentioned in all the three strata, and with the largest number of concerned focus groups in the 'Intensive agriculture' stratum (Table 3, Fig. 4). By applying fuzzy cognitive mapping 'No state support' was a common driver for all the three networks (Fig. 6). In the Ukrainian context, 'No state support' means that beekeepers feel neglected by the state authorities and left to fend for themselves with the various problems of post-Soviet legacy. Examples include uncontrolled use of pesticide by farmers, illegal transfer of pesticides across borders, use of fake pesticides, diseases of bees, natural disasters, low prices on honey and other bee products in the domestic market and limited access to the international market.

Supporting development towards what could be called sustainable landscapes (Antrop 2006) requires skills to navigate the complexity of interactions within landscapes as social-ecological systems. It is thus essential to focus both on sustainable development as an inclusive societal process (Baker 2016), and on ensuring sustainability in local landscapes and regions as a consequence of this process. This requires placebased solutions that are adapted to regional socio- ecological contexts (Potschin and Haines-Young 2013; Lazdinis et al. 2019). The term landscape approach (Sayer et al. 2013) captures this, and is illustrated by the idea of "compass and gyroscope" (Lee 1993), i.e. production of evidence-based knowledge about states and trends of sustainability dimensions, and fostering of stewardship and dialogue among stakeholders at multiple levels and sectors. The latter can be facilitated by beekeepers having bonding social capital who can collaborate with other stakeholders and actors both horizontally between networks of actors and stakeholders in an area (bridging social capital), and vertically with external vertical forms of power (linking social capital). Landscape approach thus entails collaboration among researchers, practitioners and policy makers and other stakeholders based on actions to promote a sustainable development process and sustainability in their own place and region (Angelstam et al. 2019a). At the end of the 1990s, many scholars started calling this process 'social innovation' (Moulaert et al. 2005). Collective actions has a long history in rural landscapes with traditional forms of land use (Angelstam and Elbakidze 2017; Primdahl et al. 2018), such as Ukrainian villages' beekeeping practices. Where these forms of landscape stewardship have disappeared, or did not exist, new social innovations have been proposed. Long-term socio-ecological research platform (Angelstam et al. 2019b), Model Forest (Besseau et al. 2002), and living labs (Dutilleul et al. 2010) are three examples.

This study suggests that beekeeping can be viewed as an example of a traditional practice that has the function of a social innovation. As such, beekeeping based on beekeepers with good knowledge about the ecological system, about navigating the social system's different sectors and levels of governance, as well as interactions between social and ecological systems, should be scaled up to other aspects of rural development. This is particularly relevant in a postSoviet context, as well as in the current situation with permanent efforts towards reformation in Ukraine (Krastev 2006, 2007).

\section{Conclusions}

Beekeeping is complex, and requires multiple skills in spheres of not only ecological, but also economic, 
cultural and social sustainability. Our results suggest that the hypothesis that honey bee colony losses should be higher in an intensively managed agricultural landscape compared to a traditional cultural landscape is not supported. Instead, the results from the focus groups suggest a social system hypothesis for the observed pattern. Beekeeping can be viewed a social 'glue' that strengthens the opportunity for landscape stewardship for the provision of multiple ecosystem services in particular, and rural development in general. Thus, a transdisciplinary process of knowledge production and learning focusing on systems analyses of entire SES is needed.

Acknowledgements This work was initiated at a Long-Term Socio-Ecological Research (LTSER) workshop funded by the EU eLTER project, and held in Ktura, Israel in spring 2018, and builds on the COLOSS monitoring survey in Ukraine. Many thanks to Mihai C. Adamescu from the Research Centre in Systems Ecology and Sustainability, University of Bucharest, Romania for mentoring in the use of Fuzzy Cognitive Mapping. We are thankful for comments from Mihai Adamescu, Jan Brus, Jiri Danihlik, Eva Forsgren, Alison Gray and Liza Skryzhevska, as well as three anonymous reviewers. We acknowledge funding from WTZ Project (UA 01/2017) NDR 0117 U 001774 to the scientists from Yuriy Fedkovych Chernivtsi National University and from the Swedish research council FORMAS (2017: 1342) and AlterNet to Per Angelstam.

Funding Open access funding provided by Swedish University of Agricultural Sciences.

Open Access This article is licensed under a Creative Commons Attribution 4.0 International License, which permits use, sharing, adaptation, distribution and reproduction in any medium or format, as long as you give appropriate credit to the original author(s) and the source, provide a link to the Creative Commons licence, and indicate if changes were made. The images or other third party material in this article are included in the article's Creative Commons licence, unless indicated otherwise in a credit line to the material. If material is not included in the article's Creative Commons licence and your intended use is not permitted by statutory regulation or exceeds the permitted use, you will need to obtain permission directly from the copyright holder. To view a copy of this licence, visit http://creativecommons.org/licenses/by/4.0/.

\section{References}

Agger A, Jensen JO (2015) Area-based initiatives-and their work in bonding, bridging and linking social capital. Eur Plann Stud 23(10):2045-2061

Ahmad DF, Joshi SR, Gurung MB (2007) Beekeeping and rural development. International Centre for Integrated Mountain Development, Kathmandu
André MF (1998) Depopulation, land-use change and landscape transformation in the French Massif Central. Ambio 27(4):351-353

Angelstam P, Elbakidze M (2017) Forest landscape stewardship for functional green infrastructures in Europe's West and East: diagnosing and treating social-ecological systems. In: Bieling C, Plieninger T (eds) The science and practice of landscape stewardship. Cambridge University Press, Cambridge, pp 124-144. https://doi.org/10.1017/ 9781316499016.013

Angelstam P, Grodzynskyi M, Andersson K, Axelsson R, Elbakidze M, Khoroshev A, Kruhlov I, Naumov V (2013) Measurement, collaborative learning and research for sustainable use of ecosystem services: landscape concepts and Europe as laboratory. Ambio 42(2):129-145

Angelstam P, Elbakidze M, Axelsson R, Khoroshev A, Tysiachniouk M, Pedroli B, Tysiachniouk M, Zabubenin E (2019a) Model Forests in Russia as landscape approach: demonstration projects or initiatives for learning towards sustainable forest management? For Policy Econ 101:96-110

Angelstam P, Manton M, Elbakidze M, Sijtsma F, Adamescu M, Avni N, Beja P, Bezak P, Zyablikova I, Cruz F, Bretagnolle V, Díaz-Delgado R, Ens B, Fedoriak M, Flaim G, Gingrich S, Lavi-Neeman M, Medinets S, Melecis V, Muñoz-Rojas J, Schäckermann J, Stocker-Kiss A, Setälä H, Stryamets N, Taka M, Tallec G, Tappeiner U, Törnblom J, Yamelynets T (2019b) LTSER platforms as a place-based transdisciplinary research infrastructure: learning landscape approach through evaluation. Landsc Ecol 34(7):1461-1484

Anon (2018) Death of bees near Kharkov: what is known. https://nakipelo.ua/smert-pchel-pod-harkovom-chtoizvestno/amp/. Accessed 14 June 2018 (In Ukrainian)

Antrop M (2006) Sustainable landscapes: contradiction, fiction or utopia? Landsc Urban Plann 75:187-197

Baker S (2016) Sustainable development. Routledge, London

Bengston DN (2013) Horizon scanning for environmental foresight: A review of issues and approaches. Gen. Tech. Rep. NRS-121. Newtown Square, PA: U.S. Department of Agriculture, Forest Service. https://doi.org/10.2737/NRSGTR-121

Berkes F, Folke C (1998) Linking social and ecological systems for resilience and sustainability Linking social and ecological systems: management practices and social mechanisms for building resilience. Cambridge University Press, Cambridge

Besseau P, Dansou K, Johnson F (2002) The international model forest network (IMFN): elements of success. For Dhronicle 78(5):648-654

Brodschneider R, Gray A, Adjlane N, Ballis A, Brusbardis V, Charrière JD, Chlebo R, Coffey MF, Dahle B, de Graaf DC, Dražić MM, Evans G, Fedoriak M, Forsythe I, Gregorc A, Grzęda U, Hetzroni A, Kauko L, Kristiansen P, Martikkala M, Martín-Hernández R, Medina-Flores CA, Mutinelli F, Raudmets A, Ryzhikov VA, Simon-Delso N, Stevanovic J, Uzunov A, Vejsnæs F, Wöhl S, Zammit-Mangion M, Danihlík J (2018) Multi-country loss rates of honey bee colonies during winter 2016/17 from the COLOSS survey. J Apicultural Res 57(3):452-457 
Broxton PD, Zeng X, Sulla-Menashe D, Troch PA (2014) A global land cover climatology using MODIS data. J Appl Meteor Climatol 53(6):1593-1605qw

Burneika D, Daugirdas V, Ubarevičiene R (2014) Migration as a factor of development of the depopulating areas in East EU countries-the case of Lithuania. Europa XXI 27:79-94

Cartwright BA, Collett TS (1983) Landmark learning in bees. J Comp Physiol 151(4):521-543

Diamond J (1986) Overwiew: laboratory experiments field experiments and natural experiments. In: Diamond JM, Case TJ (eds) Community ecology. Harper \& Row, New York, pp 3-22

Durham E, Baker H, Smith M, Moore E, Morgan V (2014) The BiodivERsA stakeholder engagement handbook. BiodivERsA, Paris

Dutilleul B, Birrer FA, Mensink W (2010) Unpacking European living labs: analysing innovation's social dimensions. Cent Eur J Public Policy 4(1):60-85

Eimermann M (2015) Promoting Swedish countryside in the Netherlands: international rural place marketing to attract new residents. Eur Urban Region Stud 22(4):398-415

Fedoriak MM, Angelstam PK, Kulmanov OL, Tymochko LI, Rudenko SS, Volkov RS (2019) Ukraine is moving forward from 'Undiscovered honey land' to active participation in international monitoring of honey bee colony losses. Bee World 96(2):50-54

Flick U (2018) An introduction to qualitative research. Sage Publications Limited, Thousand Oaks

Flyvbjerg B (2001) Making social science matter. Cambridge University Press, Cambridge

Gerenchuk KI (1978) Nature of Chernivtsi Region. High School Printing House, Lviv (In Ukrainian)

Goulson D, Nicholls E, Botías C, Rotheray EL (2015) Bee declines driven by combined stress from parasites, pesticides, and lack of flowers. Science 347(6229): 1255957

Gray S, Chan A, Clark D, Jordan R (2012) Modeling the integration of stakeholder knowledge in social-ecological decision-making: benefits and limitations to knowledge diversity. Ecol Modell 229:88-96

Gray SA, Gray S, De Kok JL, Helfgott AER, O’Dwyer B, Jordan R, Nyaki A (2015) Using fuzzy cognitive mapping as a participatory approach to analyze change, preferred states, and perceived resilience of social-ecological systems. Ecol Soc 20(2): 11

Gray A, Brodschneider R, Adjlane N, Ballis A, Brusbardis V, Charrière JD, Chlebo R, Coffey MF, Cornelissen B, Costa CA, Csáki T, Dahle B, Danihlík J, Dražić MM, Evans G, Fedoriak M, Forsythe I, Graaf D, Gregorc A, Johannesen J, Kauko L, Kristiansen P, Martikkala M, Martín-Hernández R, Medina-Flores CA, Mutinelli F, Patalano S, Petrov P, Raudmets A, Ryzhikov VA, Simon-Delso N, Stevanovic J, Topolska G, Uzunov A, Vejsnaes F, Williams A, ZammitMangion M, Soroker V (2019) Loss rates of honey bee colonies during winter 2017/18 in 36 countries participating in the COLOSS survey, including effects of forage sources. J Apicult Res 58(4):479-485

Hung KLJ, Kingston JM, Albrecht M, Holway A, Kohn JR (2018) The worldwide importance of honey bees as pollinators in natural habitats. Proc $R$ Soc $B$ 285(1870):20172140
Jacques A, Laurent M, Ribière-Chabert M, Saussac M, Bougeard S, Budge GE, Hendrikx P, Chauzat MP (2017) A pan-European epidemiological study reveals honey bee colony survival depends on beekeeper education and disease control. PLoS ONE 12(3):e0172591

Katchanovski I (2006) Cleft countries. Regional political divisions and cultures in post-Soviet Ukraine and Moldova. Ibidem-Verlag, Stuttgart

Keuschnigg M, Mutgan S, Hedström P (2019) Urban scaling and the regional divide. Sci Adv 5(1):eaav0042

Klein AM, Vaissiere BE, Cane JH, Steffan-Dewenter I, Cunningham SA, Kremen C, Tscharntke T (2006) Importance of pollinators in changing landscapes for world crops. Proc R Soc B 274(1608):303-313

Kosko B (1986) Fuzzy cognitive maps. Int J Man-machine Stud 24(1):65-75

Krastev I (2006) New threats to freedom: democracy's “Doubles". J Democr 17(2):52-62

Krastev I (2007) Is East-Central Europe backsliding? The strange death of the liberal consensus. $\mathrm{J}$ Democr 18(4):56-64

Kremen C, Williams NM, Aizen MA, Gemmill-Herren B, LeBuhn G, Minckley R, Packer L, Potts SG, Roulston T, Steffan-Dewenter I, Vázquez DP, Winfree R, Adams L, Crone EE, Greenleaf SS, Keitt TH, Klein AM, Regetz J, Ricketts TH (2007) Pollination and other ecosystem services produced by mobile organisms: a conceptual framework for the effects of land use change. Ecol Lett 10(4):299-314

Lazdinis M, Angelstam P, Pülzl H (2019) Towards sustainable forest management in the European Union through polycentric forest governance and integrated landscape approach. Landsc Ecol 34:1737-1749

Lee KN (1993) Compass and gyroscope: integrating science and politics for the environment. Island Press, Covelo

Lundholm E (2012) Returning home? Migration to birthplace among migrants after age 55. Popul Space Place 18(1):74-84

Lycholat O (2018) Counterfeit and fake pesticides: Causes, threats, prevention. Presentation the conference "Control of illegal transfer of pesticides across borders" held May 24-25, 2018 in Uzhgorod, Ukraine (In Ukrainian)

MacDonald D, Crabtree JR, Wiesinger G, Dax T, Stamou N, Fleury P, Lazpita JG, Gibon A (2000) Agricultural abandonment in mountain areas of Europe: environmental consequences and policy response. J Environ Manag 59(1):47-69

McGinnis MD, Ostrom E (2014) Social-ecological system framework: initial changes and continuing challenges. Ecol Soc 19(2):30. https://doi.org/10.5751/ES-06387-190230

Moulaert F, Martinelli F, Swyngedouw E, Gonzales S (2005) Towards alternative model(s) of local innovation. Urban Stud 42(11):1969-1990

Münch D, Amdam GV, Wolschin F (2008) Ageing in a eusocial insect: molecular and physiological characteristics of life span plasticity in the honey bee. Funct Ecol 22(3):407-421

Niedomysl T (2008) Residential preferences for interregional migration in Sweden: demographic, socioeconomic, and geographical determinants. Environ Plann A 40(5):1109-1131 
Oberreiter H, Brodschneider R (2020) Austrian COLOSS survey of honey bee colony winter losses 2018/19 and analysis of hive management practices. Diversity 12(3):99

Ostrom E (2009) A general framework for analyzing sustainability of social-ecological systems. Science 325(5939):419-422

Özesmi U, Özesmi SL (2004) Ecological models based on people's knowledge: a multi-step fuzzy cognitive mapping approach. Ecol Modell 176:43-64

Partelow S (2018) A review of the social-ecological systems framework: applications, methods, modifications, and challenges. Ecol Soc 23(4):36

Pascual U, Balvanera P, Díaz S, Pataki G, Roth E, Stenseke M, Watson RT, Dessane EB, Islar M, Kelemen E, Maris V (2017) Valuing nature's contributions to people: the IPBES approach. Curr Opin Environ Sustain 26:7-16

Patel V, Biggs EM, Pauli N, Boruff B (2020) Using a socialecological system approach to enhance understanding of structural interconnectivities within the beekeeping industry for sustainable decision making. Ecol Soc 25(2):24

Potschin M, Haines-Young R (2013) Landscapes, sustainability and the place-based analysis of ecosystem services. Landsc Ecol 28(6):1053-1065

Primdahl J, Kristensen L, Arler F, Angelstam P, Aagaard Christensen A, Elbakidze M (2018) Rural landscape governance and expertise-on landscape agents and democracy. In: Egoz S, Jorgensen K, Ruggeri D (eds) Defining landscape democracy: a path to spatial justice. Edward Elgar Publishing, Cheltenham, pp 153-164

Putnam RD (2001) Bowling alone: the collapse and revival of American community. Simon \& Schuster, New York

Romaniuk A, Gladun O (2015) Demographic trends in Ukraine: past, present, and future. Popul Dev Rev 41(2):315-337

Ruottinen L, Berg P, Kantanen J, Kristensen TN, Præbel A (2014) Status and conservation of the Nordic Brown Bee: final report. NordGen Publ Ser 2014:02

Sánchez-Bayo F, Wyckhuys K (2019) Worldwide decline of the entomofauna: a review of its drivers. Biol Conserv 232:8-27

Sánchez-Bayo F, Goulson D, Pennacchio F, Nazzi F, Goka K, Desneux N (2016) Are bee diseases linked to pesticides? A brief review. Environ Int 89-90:7-11

Sarchynska TG (2017) Annual statistics for Chernivtsi region. Statistical department of Chernivtsi region, Chernivtsi (In Ukrainian)

Sayer J, Sunderland T, Ghazoul J, Pfund JL, Sheil D, Meijaard E, Venter M, Boedhihartono AK, Day M, Garcia C, van Oosten C (2013) Ten principles for a landscape approach to reconciling agriculture, conservation, and other competing land uses. Proc Natl Acad Sci 110(21):8349-8356

Shackleton P, Angelstam P, van der Waal B, Elbakidze M (2017) Progress made in managing and valuing ecosystem services: a horizon scan of gaps in research, management and governance in South Africa. Ecosyst Serv 27:232-241

Sievänen T, Edwards D, Fredman P, Jensen FS, Vistad OI (eds) (2013) Social indicators in the forest sector in northern Europe: a review focusing on nature-based recreation and tourism. Nordic Council of Ministers
Skryzhevska Y, Karacsonyi D (2012) Rural population in Ukraine: assessing reality, looking for revitalization. Hung Geogr Bull 61(1):49-78

Sperandio G, Simonetto A, Carnesecchi E, Costa C, Hatjina F, Tosi S, Gilioli G (2019) Beekeeping and honey bee colony health: a review and conceptualization of beekeeping management practices implemented in Europe. Sci Total Environ 696:133795

State Statistics Service of Ukraine (2018) http://ukrstat.gov.ua/ operativ/operativ2017/ds/kn/kn_e/kn1217_e.html

Steffan-Dewenter I (2003) Importance of habitat area and landscape context for species richness of bees and wasps in fragmented orchard meadows. Conserv Biol 17(4):1036-1044

Steinhauer N, Kulhanek K, Antúnez K, Human $\mathrm{H}$, Chantawannakul P, Chauzat M-P, van Engelsdorp D (2018) Drivers of colony losses. Curr Opin Insect Sci 26:142-148

Sutherland WJ, Woodroof HJ (2009) The need for environmental horizon scanning. Trends Ecol Evol 24:523-527

Szopek M, Schmickl T, Thenius R, Radspieler G, Crailsheim K (2013) Dynamics of collective decision making of honeybees in complex temperature fields. PLoS ONE 8(10):e76250

Szreter S, Woolcock M (2004) Health by association? Social capital, social theory, and the political economy of public health. Int Epidemiol 33(4):650-667

Ubarevičienè R, Van Ham M (2017) Population decline in Lithuania: who lives in declining regions and who leaves? Region Stud Region Sci 4(1):57-79

van der Zee R, Gray A, Holzmann C, Pisa L, Brodschneider R, Chlebo R, Coffey MF, Kence A, Kristiansen P, Mutinelli F, Nguyen BK, Noureddine A, Peterson M, Soroker V, Topolska G, Vejsnæs F, Wilkins S (2013) Standard survey methods for estimating colony losses and explanatory risk factors in Apis mellifera. J Apicult Res 52(4):1-36

Vandame R, Palacio MA (2010) Preserved honey bee health in Latin America: a fragile equilibrium due to low-intensity agriculture and beekeeping? Apidologie 41:243-255

Von Frisch K, Chadwick LE (1967) The dance language and orientation of bees, vol 1. Belknap Press of Harvard University Press, Cambridge

Wenner AM, Meade DE, Friesen LJ (1991) Recruitment, search behavior, and flight ranges of honey bees. Am Zool 31(6):768-782

Winston ML (1991) The biology of the honey bee. Harvard University Press, Cambridge

Wood TJ, Michez D, Paxton RJ, Drossart M, Neumann P, Gérard M, Vanderplanck M, Barraud A, Martinet B, Leclercq N, Vereecken NJ (2020) Managed honey bees as a radar for wild bee decline? Apidologie. https://doi.org/10. 1007/s13592-020-00788-9

Publisher's Note Springer Nature remains neutral with regard to jurisdictional claims in published maps and institutional affiliations. 